\title{
GAIN OF FunCTION MutanTs: Ion Channels and G Protein-Coupled Receptors
}

\author{
Henry A. Lester ${ }^{1}$ and Andreas Karschin ${ }^{2}$ \\ ${ }^{1}$ Division of Biology, California Institute of Technology, Pasadena, California 91125; \\ e-mail: Lester@caltech.edu; ${ }^{2}$ Department of Molecular Neurobiology of Signal \\ Transduction, Max-Planck-Institute for Biophysical Chemistry, 37070; Göttingen, \\ Germany; e-mail: akarsch@gwdg.de
}

Key Words epilepsy, neurodegeneration, long-QT syndrome, weaver, genetic disease

- Abstract Many ion channels and receptors display striking phenotypes for gainof-function mutations but milder phenotypes for null mutations. Gain of molecular function can have several mechanistic bases: selectivity changes, gating changes including constitutive activation and slowed inactivation, elimination of a subunit that enhances inactivation, decreased drug sensitivity, changes in regulation or trafficking of the channel, or induction of apoptosis. Decreased firing frequency can occur via increased function of $\mathrm{K}^{+}$or $\mathrm{Cl}^{-}$channels. Channel mutants also cause gain-of-function syndromes at the cellular and circuit level; of these syndromes, the cardiac long-QT syndromes are explained in a more straightforward way than are the epilepsies. G proteincoupled receptors are also affected by activating mutations.

"Happy families are all alike. Each unhappy family has its own story." Anna Karenina

L. Tolstoy

\section{INTRODUCTION}

This chapter is motivated by two observations. First, many ion channels and receptors manifest striking dominant or semidominant phenotypes for specific gain-of-function mutations but much milder phenotypes for null mutations. We survey several examples: the weaver and lurcher mouse, the degenerins of Caenorhabditis elegans, and engineered mutations of GluR-B editing.

Second, every major electrically excitable organ is associated with a spectrum of genetic diseases involving impulses (action potentials) that are either too frequent or too long. These gain-of-function changes at the cellular or circuit level arise from either gain or loss of function at the molecular level. In placing these diseases in their physiological context, we emphasize the epilepsies and-for the convenience of neuroscientists not acquainted with analogous events in heart- 
long-QT syndrome. This chapter concentrates on ion channels but also includes comments on gain-of-function mutations in $\mathrm{G}$ protein-coupled receptors. Genetically based skeletal myopathies were recently reviewed in this series (Cannon 1996) and elsewhere (Jentsch et al 1995); hyperinsulinism due to $\mathrm{K}_{\mathrm{ATP}}$ channels was reviewed in a related series (Babenko et al 1998).

A generally useful viewpoint centers on optimization mechanisms that endow highly evolved nervous systems to process information with maximal speed and density and with minimal energy consumption. We give some examples of these mechanisms: (a) Inward rectifier $\mathrm{K}^{+}$channels minimize ion flow during activity; (b) glia siphon extracellular $\mathrm{K}^{+}$away from neurons following activity; (c) many molecules and mechanisms render the synapse an efficient organelle on a timescale of milliseconds and a distance scale of micrometers; $(d)$ myelin increases the speed and decreases the energy cost of nerve impulses; and $(e)$ blood flow and oxygenation are efficiently adjusted locally during activity. This chapter includes examples of pathology in the first three mechanisms caused by gain-offunction mutations in ion channels and receptors. The most common examples of demyelinating diseases, however, have an autoimmune basis and do not arise directly from excitability proteins, and the details of the last mechanism are still not settled.

Transporters also control membrane excitability. We note here, but do not discuss further, that a disrupted NHE1 $\mathrm{Na}^{+} / \mathrm{H}^{+}$exchanger causes recessive slowwave epilepsy in mice (Cox et al 1997), that an important literature is emerging on mice with disrupted neurotransmitter transporters, and that the serotonin transporter exhibits a promoter region polymorphism linked to personality differences and psychiatric diseases (McGue \& Bouchard 1998).

\section{MOLECULAR GAIN OF FUNCTION: A MECHANISTIC SURVEY}

\section{Selectivity Changes}

Weaver The weaver mouse represents a particularly well-understood gain-offunction neurological mutation; but as is shown, there remain certain puzzling aspects of the weaver phenotype. In weaver mice (wv), the $\mathrm{G}$ protein-gated inward rectifier channel GIRK2, Kir3.2, is mutated (Patil et al 1995). Homozygous GIRK2 knockout mice display a much less severe phenotype, leaving no doubt that weaver is a gain-of-function disease (Luscher et al 1997, Signorini et al 1997, Slesinger et al 1997). The weaver GIRK2 channel actually displays three gain-of-function characteristics.

In the wvGIRK2 gene, the single-nucleotide mutation changes the well-conserved glycine-tyrosine-glycine (GYG) motif, found in nearly all $\mathrm{K}^{+}$channels, to SYG. In the crystal structure of the Streptomyces lividans $\mathrm{K}^{+}$channel, the aligning Gly residue is at the heart of the permeation pathway and appears flanked, 
within a few angstroms, by two permeant ions (Doyle et al 1998). Although there is no crystal structure for the Gly $>$ Ser mutant, it is apparent that this crucial mutation would change the shape of the permeation pathway, and this shape change presents an explanation, at a resolution of angstroms but perhaps not at the subangstrom level, for the general agreement that the mutated channel has altered selectivity: The wvGIRK2 channel has roughly equal permeability for $\mathrm{Na}^{+}$and $\mathrm{K}^{+}$(Kofuji et al 1996, Navarro et al 1996, Slesinger et al 1996, Tong et al 1996, Tucker et al 1996), with some permeability for $\mathrm{Ca}^{2+}$ as well (Silverman et al 1996). A previous report shows that certain other mutations in the GYG motif of Shaker also produce a loss of selectivity (Heginbotham et al 1994). A subsequent report was motivated by the fact that most [but not all (Inanobe et al 1999)] GIRK channels are heteromultimers between GIRK1 (Kir3.1), and another GIRK subunit, such as GIRK2 or GIRK4 (Kir3.4). This report shows that permeation is governed asymmetrically by the two GIRK1 subunits versus the other two GIRK subunits (Silverman et al 1998).

The changed lumen also provides an acceptable explanation for a second gainof-function characteristic of the weaver channel: wvGIRK2 is more susceptibleby at least a factor of 10-to several drugs (Kofuji et al 1996) thought to block other cation channels by binding directly within the lumen. These drugs include QX-314 (which blocks voltage-gated $\mathrm{Na}^{+}$channels from the intracellular surface and nicotinic receptors from the extracellular surface), verapamil (which blocks L-type $\mathrm{Ca}^{2+}$ channels), and MK-801 (which blocks NMDA receptor channels and nicotinic receptor channels). This gain of pharmacological function provided a chance to test the hypothesis that cells die because of the increased $\mathrm{Na}^{+}$or $\mathrm{Ca}^{2+}$ influx: Purified weaver granule cells normally die after several days in culture; but incubation with QX-314 (Kofuji et al 1996, Harkins et al 1998), verapamil (Kofuji et al 1996, Liesi \& Wright 1996), or MK-801 (Kofuji et al 1996, Liesi \& Wright 1996) rescued cell viability, neurite extension, and TAG1 antigen expression. Also, $\mathrm{Ca}^{2+}$-free external solutions promote the survival of oocytes expressing wvGIRK2 (Tucker et al 1996), wv granule cells survive better if intracellular $\mathrm{Ca}^{2+}$ is lowered by exposure to BAPTA-AM (Liesi et al 1997), and wv/ + granule cells have elevated $\left[\mathrm{Ca}^{2+}\right]$ (Fox et al 1998). These results are explained either by direct flux of $\mathrm{Ca}^{2+}$ through the weaver channel (Silverman et al 1996) or by the fact that the sustained $\mathrm{Na}^{+}$influx eventually depletes $(a)$ the $\mathrm{Na}^{+}$ concentration gradient required to drive the $\mathrm{Na}^{+} / \mathrm{Ca}^{2+}$ exchanger or $(b)$ the ATP levels required to maintain low intracellular $\mathrm{Ca}^{2+}$ via active intracellular pumps.

The changed lumen does not, however, account directly for a third gain of function. The weaver GIRK2 channel is "constitutively" activated (Kofuji et al 1996, Slesinger et al 1997): Both weaver granule cells and oocytes expressing wvGIRK2 display a standing $\mathrm{Na}^{+}$current that is blocked by QX-314 (Kofuji et al 1996). There is, of course, ample precedent for the idea that ion channels mutated in the permeation pathway display more stable open states, presumably because the permeation pathway is also in contact with the regions of the channel thought to govern gating (Revah et al 1991, De Biasi et al 1993, Labarca et al 
1995), but the argument is less direct than for the permeation pathway. Furthermore, several reports showed no constitutive activation of the wvGIRK2 channel-and no GIRK currents at all-in weaver mice (Mjaatvedt et al 1995, Surmeier et al 1996, Lauritzen et al 1997), and constitutive activation was incomplete when only low levels of wvGIRK2 were expressed in oocytes (Slesinger et al 1996). Also, wvGIRK2 channels were insensitive to $G$ protein subunits in excised inside-out patches from CHO cells (Navarro et al 1996).

These inconsistent reports about constitutive activation prompted us to search for an uncontrolled variable in experiments on the wvGIRK2 channel. An important clue was provided by reports that GIRK channels are activated directly by intracellular $\mathrm{Na}^{+}$concentration on the order of several tens of millimolars (Lesage et al 1995, Sui et al 1996). Asp226 in the proximal C terminus of GIRK2 appears to play a crucial role in this $\mathrm{Na}^{+}$-dependent gating (Ho \& Murrell-Lagnado 1999). Constitutive activation could be distinguished from $\mathrm{Na}^{+}$permeability as follows. Oocytes expressing the muscarinic M2 receptor and wvGIRK2 were induced to maintain low intracellular $\mathrm{Na}^{+}$by incubation in an elevated external $\mathrm{K}^{+}$, low$\mathrm{Na}^{+}$solution supplemented with external glucose. These oocytes were compared with oocytes maintained in normal Ringer solution or in solution with ouabain. In the oocytes with low intracellular $\mathrm{Na}^{+}$, the $\mathrm{Na}^{+}$permeability was increased by $\sim 20 \%$ when ACh was added, showing that additional wvGIRK2 channels were recruited by liberation of $G$ protein subunits. In the oocyte with high internal $\mathrm{Na}^{+}$, on the other hand, the standing $\mathrm{Na}^{+}$permeability was already high and was not further increased by $\mathrm{ACh}$, presumably because the GIRK channels were already activated. These results suggest that although $\mathrm{Na}^{+}$permeability results directly from the Gly $>$ Ser mutation, constitutive activation of the GIRK2 channels is not a direct consequence but arises instead via the increased intracellular $\mathrm{Na}^{+}$concentration. In short, we hypothesized a regenerative pathophysiological mechanism: The $\mathrm{Na}^{+}$-permeable channel leads to increased intracellular $\mathrm{Na}^{+}$; this in turn activates the channel further. This regenerative mechanism presumably takes on particular importance in small cells, where the high surface-tovolume ratio implies that flux of $\mathrm{Na}^{+}$at the membrane is an important metabolic load on the entire cytoplasmic $\mathrm{Na}^{+}$concentration. In addition to degeneration of the cerebellar granule cells that express GIRK2, weaver mice also display defects in other small cells, including the granule cells of the substantia nigra (RofflerTarlov et al 1996), olfactory bulb (Schein et al 1998), and hippocampus (Sekiguchi et al 1995).

Although all cells that die in weaver express GIRK2 (Harrison \& RofflerTarlov 1998, Schein et al 1998), not all cells that express GIRK2 die. Based on the discussion above, this selective death could arise from one or more of the following factors: heteromultimeric versus homomultimeric channels; the time of expression; a cell's surface-to-volume ratio; a cell's ability to handle $\mathrm{Na}^{+}$and/or $\mathrm{Ca}^{2+}$ overloads; and signal transduction pathways that might normally inactivate GIRK channels, for instance via phosphorylation (Velimirovic et al 1995). Only the latter mechanism seems capable of explaining the most puzzling aspect of the 
weaver phenotype: When cocultured with or implanted into wild-type external germinal layer, weaver granule cells differentiate normally, including the extension of parallel fibers, migration through the molecular and Purkinje cell layers, positioning in the internal granule cell layer, and extension of dendrites (Gao et al 1992, Gao \& Hatten 1993). Direct experiments testing the hypothesis that the apparently cell-autonomous defect in the weaver GIRK2 channel is indeed suppressed by a signal from neighboring cells have not been reported.

GluR-B Editing Several non-NMDA glutamate receptors are edited at the mRNA level, with resulting significant differences in function (Seeburg et al 1998, Dingledine et al 1999). The best studied, and for the moment most dramatic result, is the $\mathrm{Q} / \mathrm{R}$ codon in GluR-B. The genomic sequence encodes Gln (CAG), but an interaction between the adjacent intron and the editing enzyme RNA adenosine deaminase (dsRAD) results in an mRNA that encodes Arg (CGG). Receptors containing the unedited Gln residue have higher $\mathrm{Ca}^{2+}$ permeability, higher single-channel conductance, and nonlinear single-channel current-voltage relations.

In the first attempt to manipulate editing, a gain-of-function mutation was produced by deleting a portion of the intron sequence. In heterozygous mice, roughly $25 \%$ of the GluR-B sequences were unedited. The mice developed seizures and died by 3 days of age. Clearly the editing is crucial for correct development (Brusa et al 1995).

The $\mathrm{Q}$ form of GluR-B is expressed in adult brain at very low levels $(<0.1 \%$ of $\mathrm{R}$ form) (Sommer et al 1991), but it represents up to 20\% of GluR-B mRNA during early embryonic development (Kask et al 1998). Does the small amount of unedited GluR-B - with its small amount of $\mathrm{Ca}^{2+}$ influx - play a role in normal development or function? Initial results from a clever knock-in experiment suggest that this is not the case. The wild-type Gln codon was mutated to Arg, with no obvious change in brain histology or AMPA currents in excised nucleated patches from CA1 neurons (Kask et al 1998).

A line of mice was also made from an intermediate construct in the knock-in process; this line carries an intact neo selection cassette in the adjacent intron. In these mice, the undeleted intron reduced GluR-B by $30 \%$ and therefore led to receptors with too few edited GluR-B subunits and roughly twice the normal $\mathrm{Ca}^{2+}$ influx through AMPA receptors of CA1 neurons. There were no obvious developmental or physiological anomalies in these mice. Complete disruption of the GluR-B gene does lead to some impairments in open-field behavior and motor coordination as well as to NMDA-independent long-term potentiation (Jia et al 1996).

One spectator sport has been to comment on the reason that nature has conserved the genomic glutamine residue and editing mechanism, rather than the apparently more straightforward mechanism of the genomic glutamine residue. There is no clear resolution of this point (Seeburg et al 1998, Dingledine et al 1999). 
A series of mice have been generated that carry various levels of $\mathrm{Ca}^{2+}$ entry in their AMPA receptors (Feldmeyer et al 1999). This was accomplished by retaining another intermediate, the loxP-flanked selection cassette of Brusa et al (1995), as well as by construction of a transgenic line containing the unedited GluR-B subunit. Mice with moderately increased numbers of $\mathrm{Ca}^{2+}$-permeable, higher-conductance AMPA receptors showed epileptic seizures and premature death (P20 to P25). Mice with 30-fold increases in $\mathrm{Ca}^{2+}$ influx died earlier (P4$\mathrm{P} 20$ ), with no obvious seizures. All the mutants with increased $\mathrm{Ca}^{2+}$ permeability showed NMDA-independent long-term potentiation, like the GluR-B knockout mice. There was no obvious evidence for cell-autonomous death in the neurons expressing the altered receptors; instead, the authors claim that "the deleterious effects of calcium in our mutants seem to arise from altered network properties" (Feldmeyer et al 1999).

\section{Gating Changes: Constitutive Activation}

Lurcher The lurcher $(L c)$ gene encodes the $\delta 2$ putative glutamate receptor (Zuo et al 1997). The lurcher mutation, an alanine-to-threonine substitution, occurs in a domain of nine residues that is highly conserved among known members of the ionotropic glutamate receptor family. In heterozygous $L c$ mice, some cerebellar Purkinje cells die in the second and third postnatal weeks; this causes ataxia. In homozygotes, most Purkinje cells die, and the mice die soon after birth.

The $L c \delta 2$ gene product is a constitutively active cation channel (Zuo et al 1997). Purkinje cells from heterozygotes have a depolarized resting potential and a high resting conductance; and the $L c \delta 2$ receptor-expressing oocytes have a constitutively active conductance for $\mathrm{Na}^{+}$(but not for NMDG). This gain of function produced by the mutation explains the complete Lurcher phenotype: both the cellular specificity and the timing of cell death.

It is not clear what the wild-type $\delta 2$ receptor does, despite its homology to glutamate receptors. The $\delta 2$ receptor is found in both shafts and spines of Purkinje dendrites in the early postnatal period and occurs at climbing fiber synapses only at P10 and P14 (Zhao et al 1998). By P21, however, the intense immunoreactivity is restricted to the dendritic spines, especially along the postsynaptic membrane in contact with parallel fiber terminals (Takayama et al 1996). In $\delta 2$ knockout mice, there are fewer parallel fiber-to-Purkinje cell synapses (Kurihara et al 1997). The phenotype of these knockout mice, including mild recessive ataxia, is identical to that of Hotfoot mice, which have at least eight independent alleles that are all probably reduced or null $\delta 2$ receptors (Lalouette et al 1998).

Despite these clear indications that the wild-type $\delta 2$ receptor plays an important role in synaptic transmission to Purkinje cells, the wild-type gene product from the lurcher locus has not been expressed functionally in a heterologous system. Even if the $\delta 2$ receptor does form part of a functional channel, there are many possible reasons for this failure (Lester 1988). There are no clear physiological responses corresponding to the $\delta 2$ receptor in wild-type Purkinje cells. 
A related experiment has, however, given useful data (M Yuzaki, personal communication): The mutation aligning to the lurcher mutation caused constitutively active AMPA and kainate receptors. The mutant channels retained their wild-type channel characteristics, such as $\mathrm{Ca}^{2+}$ permeability, rectification, and antagonist profiles. Although NMDA receptors with the lurcher mutation did not show frank constitutive activation, they did show delayed deactivation in response to agonist pulses. Thus, the lurcher mutation occurs in a region of general importance for glutamate receptor gating.

Slow-Channel Syndrome Recent data suggest that slow-channel congenital myasthenic syndrome arises from a form of constitutive activation (Zhou et al 1999). Slow-channel congenital myasthenic syndrome is caused by dominant mutations in human muscle nicotinic acetylcholine receptors, resulting in muscle weakness and fatigue, especially revealed by staircase summation of the prolonged endplate potentials leading to a depolarization block at moderate rates $(20-40 \mathrm{~Hz})$ of stimulation. Electron microscope observations reveal that the syndrome is accompanied by various defects in the postsynaptic junctional folds (Engel et al 1992, 1999). Alleles occur in the $\alpha, \beta$, and $\varepsilon$ subunits (Gomez \& Gammack 1995; Gomez et al 1996b, 1998). Several slow-channel alleles produce hypersensitive receptors, with dose-response relations for acetylcholine shifted to the left. Single-channel analysis from the Sine and Auerbach labs previously disclosed the microscopic bases for these shifted dose-response relations: In general, the pore mutations increase ACh-activated currents by increasing the openchannel duration, whereas mutations at or near the agonist binding site increase the rate of opening (Ohno et al 1995, Sine et al 1995, Engel et al 1996, Milone et al 1997, Wang et al 1997).

Zhou et al (1999) have shown, additionally, that several slow-channel mutations produce receptors activated by choline. The $50 \%$ effective concentration for choline is between $500 \mu \mathrm{M}$ and $3 \mathrm{mM}$, which causes detectable activation at choline concentrations normally found in extracellular fluid; indeed, serum does activate the mutant receptors. Most of this increased activation occurs because the receptors with two bound choline molecules isomerize more easily than do wild-type receptors to the open-channel state. The ratio of open to closed cholinebiliganded receptors is only 0.015 for wild type but between 0.11 and 1.8 for the slow-channel alleles. The calculated ion flux due to serum choline is several times greater than that for normal excitation at a frequency of 120 impulses/min. Furthermore, choline desensitizes at least one of the alleles, $\alpha \mathrm{V} 249 \mathrm{~F}$; this is revealed by clusters of single-channel activity separated by the silent "desensitized" periods. The sustained circulating choline is likely to be a more important activator of the channels than is the $\sim 1$-ms burst of higher concentration shaped by esteratic hydrolysis of ACh during synaptic events.

There are also data on the electron microscope anatomy of endplates and muscle weakness, both in slow-channel patients (Engel et al 1992) and in transgenic mice that display slow-channel syndrome because they overexpress AChR sub- 
units that confer hyperexcitability (Gomez et al 1996a, 1997). Previous data, however, showed no apparent correlation between the severity of the syndrome and the endplate current decay times (Gomez et al 1998). It has been reported (A Engel, personal communication) that the pore mutations caused the most severe symptoms and the external binding mutations (e.g. $\alpha \mathrm{G} 153 \mathrm{~S}$ ) the least serious. The present challenge is to explain the greatly varying pathologies of the slowchannel alleles in terms of the several possible underlying mechanisms: $(a)$ excess activation during endplate potentials; $(b)$ desensitization by acetylcholine during endplate potentials (Bhattacharyya et al 1997); (c) excess activation by circulating choline; and $(d)$ desensitization by circulating choline.

Neuronal nAChR Gain of Function Mutations? In light of these important results with slow-channel alleles, the hypothesis of activation or desensitization by a circulating molecule should also be tested with three neuronal nAChR mutations. The first is autosomal dominant nocturnal frontal-lobe epilepsy (ADNFLE), caused by either of two alleles in the M2 region of the $\alpha 4$ receptor (Steinlein et al 1997). Several groups have conducted electrophysiological studies of the mutant allele expressed in oocytes and mammalian cells (Kuryatov et al 1997, Bertrand et al 1998, Figl et al 1998). There are several physiological differences from wild-type receptors in single-channel duration, dose-response relation, desensitization, and $\mathrm{Ca}^{2+}$ permeability. Two characteristics shared between the two alleles are reduced permeability to calcium and enhanced desensitization (Bertrand et al 1998). Another characteristic shared between the two alleles is a "run-up" phenomenon in which successive applications of acetylcholine produce larger responses (Kuryatov et al 1997, Figl et al 1998). Figl et al (1998) speculated that this phenomenon represented relief of blockade, although no blocker was intentionally added to the solution bathing the oocytes. Perhaps a desensitizing agent was being released from the cells or from the perfusion system. The possibility that ADNFLE alleles are hyperactive (Forman et al 1996) should also be considered in light of the fact that one allele is a Ser to Phe mutation at the 6' position of M2 [numbering system as in Charnet et al (1990)]. In the skeletal muscle $\beta$ subunit, the aligning mutation is known to confer increased sensitivity (Leonard et al 1988).

Second, one phenotype of the ADNFLE mutations-slow activation-resembles that of the C. elegans DEG-3 u662 allele when expressed with its immediate upstream neighbor, DES-2. The two genes are part of the same operon (Treinin et al 1998) and are homologous to nAChR subunits, and because it has adjacent cys residues, DES-2 probably encodes an $\alpha$-like subunit. The DEG-3 u662 phenotype is degeneration in the small set of neurons that express both proteins (Treinin \& Chalfie 1995); truncations of DES-2 suppress this phenotype. This observation fits with the observation that neither protein alone produces a functional nAChR in oocytes, but coexpression produces responses to $\mathrm{ACh}$. The DEG-3 u662 Ile-to-Asn mutation is at position 13' in the M2 domain (Treinin \& Chalfie 1995) and would be expected to produce a hypersensitive nAChR, yet 
there were no obvious standing currents in the oocytes coinjected with cRNA for DES-2 and DEG-3 u662 (Treinin et al 1998). This mutant should be tested for activation by choline.

The third nAChR candidate for constitutive activation is the $\alpha 7$ knock-in mouse containing a Leu-to-Thr mutation at the M2 9' position (Orr-Urtreger, A Beaudet, J Patrick, submitted for publication). This mouse was constructed because pioneering data in heterologous expression showed that this mutation shifted the doseresponse relation to the left and reduced desensitization (Revah et al 1991). Several antagonists or partial agonists at the wild-type receptor became agonists at the mutant receptor. Furthermore, the mutation displays spontaneous activity in the absence of agonists (Bertrand et al 1997). The homozygote, which would have homomultimeric mutant $\alpha 7$ receptors, is lethal. It is now necessary to test whether the lethality arises because of excessive $\mathrm{Ca}^{2+}$ influx through the mutant receptor. Does this excessive influx arise because of $(a)$ spontaneous activation, $(b)$ evoked activation by synaptically liberated $\mathrm{ACh}$, or $(c)$ activation by choline? Our laboratory has now constructed two analogous knock-in mice. One has the aligning mutation in the $\alpha 4$ receptor; the heterozygotes die just after birth (C Labarca, P Deshpande, P Kofuji, B Khakh, M Nowak, Z Chen, J Boulter, and HA Lester, unpublished data). The other has a closely related hyperexcitable mutation in the serotonin 5-HT 3 A receptor; the homozygotes are viable (Dang et al 1999).

Degenerins The degenerins of C. elegans include DEG-1, MEC-4, DEL-1, MEC-10, UNC-8, and UNC-105 (Garcia-Anoveros et al 1998). Because most degenerins are expressed in mechanosensory neurons (or cells with suspected mechanosensory abilities such as muscle), they are thought to form one subunit of mechanosensitive channels. The degenerins are homologous to the amiloridesensitive epithelial $\mathrm{Na}^{+}$channel (ENaC) (Canessa et al 1993, 1994), the amiloride-sensitive mammalian neuronal $\mathrm{Na}^{+}$channels (BNaC1/BNC1/mDEG1; BNaC2/ASIC) (Waldmann et al 1996, Price et al 1996, Garcia-Anoveros et al 1997) and the related DRASIC, the FMRFamide-peptide-activated channel from Helix aspersa $(\mathrm{FaNaC})$ (Lingueglia et al 1995), and the ripped pocket (RPK) and pickpocket (PPK) genes of Drosophila (Adams et al 1998a).

C. elegans neurons expressing some degenerin mutants swell to several times their original diameter, accumulate whorls, and sometimes die. It has long been suspected that the cause of this pathology is a gain-of-function mutation in ion channels encoded by these genes (Driscoll 1992; Huang \& Chalfie 1994; GarciaAnoveros et al 1995, 1998; Shreffler et al 1995; Tavernarakis \& Driscoll 1997). A related mutant causes constitutive contraction of muscle (Liu et al 1996). Three classes of alleles are known: residues in the extracellular domain, residues in the putative membrane-spanning pore region (reminiscent of the two classes of mutations known in nAChR slow-channel mutants), and residues in the muscle homolog UNC-105 near the extracellular ends of the two transmembrane domains. Deletion of nine amino acids surrounding the mutation site in mec- 4 also causes neuronal degeneration (Garcia-Anoveros et al 1995). However, this mutation is 
recessive, unlike the dominant MEC-4 point mutations. Garcia-Anoveros et al (1995) proposed that the putative channel is a homomultimer with several redundant extracellular inhibitory domains (i.e. gates), so that most channels formed in heterozygotes would have at least one normal subunit, sufficient to keep the channel closed. This model may apply to recessive gain-of-function mutations in other channels and also to any multimeric protein with redundant inhibitory domains.

Recently, direct proof was obtained for some of these ideas. UNC-105, which appeared likely from sequence and genetic analysis to be an ancestral channel and therefore to function as a homo-oligomer (Garcia-Anoveros et al 1995), was expressed in both mammalian cells and oocytes either with P134S, a known allele of UNC-105, or with A692V, a mutation aligning with the degeneration-causing mutation of other degenerins. Both mutations did indeed produce constitutively active cation channels. The channels killed mammalian cells, producing vacuoles and membranous whorls like those found in degenerating $C$. elegans neurons (Garcia-Anoveros et al 1998).

The aligning mutation in $\mathrm{BNaC} 1 / \mathrm{BNC} 1 / \mathrm{mDEG} 1$ produces constitutive activation (Waldmann et al 1996). In an interesting variation of this experiment on this channel with a cys mutation at the aligning position, if methanethiosulfonate reagents were added during reversible activation by low $\mathrm{pH}$, activation became permanent. This is completely consistent with the view that a bulky residue at this position favors activation (Adams et al 1998b). The aligning mutation in ripped pocket (RPL) generates constitutively active $\mathrm{Na}^{+}$channels (Adams et al 1998a).

It is known that the acid-activated channel of dorsal root ganglion loses $\mathrm{Na}^{+}$ selectivity after a few seconds of activation: Its reversal potential changes to near zero, as though it is permeable to both $\mathrm{Na}^{+}$and $\mathrm{K}^{+}$(Bevan \& Yeats 1991). Likewise, heteromers between an mDEG1 splice variant and DRASIC, which appears to be expressed in dorsal root ganglion neurons, acquired nonselective characteristics after a few seconds of activation (Lingueglia et al 1997). Finally, the combination of mDEG1 with mutant ASIC also becomes nonselectively permeable (Bassilana et al 1997).

\section{More Subtle Gating Changes}

Persistent Activation in Voltage-Gated $\mathrm{Na}^{+}$Channels The voltage-gated $\mathrm{Na}^{+}$ channels of each electrically excitable organ (brain, peripheral nerve, heart, skeletal muscle, and pancreas) appear to be fine-tuned for the frequency and waveform of action potentials; furthermore, the repertoire of expressed $\mathrm{Na}^{+}$channels changes as frequency and waveform change with the developmental state (Ruff 1998). It is not surprising that most characterized gain-of-function point mutations in $\mathrm{Na}^{+}$channels involve decreased inactivation or deactivation (Cannon 1996), for the following reasons. (a) $\mathrm{Na}^{+}$channels already activate so quickly that even faster activation is unlikely to change coding properties and is also unlikely to be 
measurable, although activation shifted to more negative potentials may cause persistent activation (Hayward et al 1996). (b) Mutations that increase singlechannel conductance would probably involve only a few regions of the protein, would be measurable only in single-channel experiments, and possibly also would change ion selectivity. (c) On the other hand, inactivation can be measured with only moderately good voltage clamps, it occurs over a range of timescales from milliseconds to seconds, it involves many parts of the channel protein, and it can be phenocopied by many toxins. Defective deactivation from the excited state, another process that shuts off channels, causes some alleles $(a)$ of human myotonia (muscle stiffness) that are aggravated by elevated $\mathrm{K}^{+}$(Richmond et al 1997), and $(b)$ of paramyotonia congenita (exercise- and cold-exacerbated muscle hyperexcitability) (Featherstone et al 1998).

The paralyses (hyperkalemic periodic paralysis, hypokalemic periodic paralysis) are the only $\mathrm{Na}^{+}$channel diseases currently known to be caused by depolarizing block. However, in a recent report, the $\triangle \mathrm{KPQ}$ allele of long-QT (LQT) syndrome displays slowed recovery from inactivation, and this may underlie the arrhythmia associated with LQT syndrome type 3 (described below) (Nagatomo et al 1998).

Elimination of a Subunit that Enhances Inactivation The $\beta$ subunits (Kv $\beta)$ of some voltage-dependent channels confer fast inactivation; therefore suppression of $\mathrm{Kv} \beta$ subunits might have a gain-of-function phenotype for $\mathrm{K}^{+}$channels. Giese et al (1998) disrupted the gene for $\mathrm{Kv} \beta 1.1$, which interacts with the $\alpha$ subunits $\mathrm{Kv} 1.1, \mathrm{Kv} 1.2$, and Kv1.4. As expected, the mutant mice displayed smaller inactivating $\mathrm{K}^{+}$currents $\left(\mathrm{I}_{\mathrm{A}}\right)$ and larger maintained $\mathrm{K}^{+}$currents. (There was also a small decrease in peak $\mathrm{K}^{+}$currents, consistent with in vitro experiments showing that $\mathrm{Kv} \beta 1.1$ may act as a chaperone to increase the expression of Kv1.x channels.) The mutant mice showed decreased frequency-dependent spike broadening and decreased slow after-hyperpolarization (SAHP) — an elegant confirmation of present concepts about the role of transient $\mathrm{K}^{+}$currents, and a confirmation that could not be obtained by other means, because there are few specific blocking drugs for these channels. It is interesting that the mice also displayed specific defects in learning and memory - an even more important demonstration that changes in ion kinetics do influence higher neuronal functions. Because some theories of cognitive decline involve increases in the slow after-hyperpolarization of aged neurons, it is interesting to note that aged mutant mice have improved learning and memory in three hippocampus-dependent tasks ( $N$ Fedorov, K Giese, M Ohno, E Friedman \& A Silva, submitted for publication). Kv1.1 antisense knockdown also eliminates after-hyperpolarization (Meiri et al 1997), and Kv1.4 knockdown inhibits long-term potentiation (Meiri et al 1998).

Below are described several other instances of malfunction caused by lack of a subunit in voltage-gated $\mathrm{K}^{+}, \mathrm{Na}^{+}$, or $\mathrm{Ca}^{2+}$ channels. A particularly comprehensive review on ion channel diseases caused by voltage-gated channels has recently appeared (Lehmann-Horn \& Jurkatt-Rott 1999). 


\section{Decreased Drug Sensitivity}

Some insecticides, such as pyrethroids and DDT, interfere with $\mathrm{Na}^{+}$channel inactivation, producing hyperactivity that can kill insects, just as acetylcholinesterase poisons kill them. The small size of insect neurons and tightly packed insect neuropil may aggravate changes in intracellular or extracellular ion concentrations. For nearly a decade, it has been known that pyrethroid insecticide resistance maps to the para locus, which encodes the predominant voltage-gated $\mathrm{Na}^{+}$channel (Loughney et al 1989, Ramaswami \& Tanouye 1989) in Drosophila and other species (Williamson et al 1993, Dong \& Scott 1994, Miyazaki et al 1996, Martinez-Torres et al 1998, Zlotkin 1999); in housefly, this is the $k d r$ locus (Knipple et al 1994, Miyazaki et al 1996). Heterologous expression of this channel requires the TipE gene product as well (Feng et al 1995, Warmke et al 1997). Sequencing reveals that a pyrethroid-resistance mutant of the housefly $k d r$ gene has a Leuto-Phe mutation in IIS6; the super-kdr allele has this mutation as well as a Metto-Thr mutation in the IIS4-S5 loop, and the aligning mutation accounts for pyrethroid resistance in Heliothis virescens (Park \& Taylor 1997). In one molecular interpretation of these mutations, pyrethroids bind to the intracellular mouth of the channel (Williamson et al 1996). Expression reveals that these mutations, alone or in combination, yield pyrethroid-resistant $\mathrm{Na}^{+}$channels (Smith et al 1997, Lee et al 1999). Similarly, a cockroach pyrethroid-resistant $\mathrm{Na}^{+}$channel has a Leu-to-Phe mutation in IIS6 (Dong 1997).

A different interpretation of insecticide resistance was offered by Pittrendrigh et al (1997). DDT-resistant alleles of Drosophila have mutations at the IS4-S5 loop $\left(\right.$ para $\left.^{t s I}\right)$, the IIIS4-S5 loop ( para $^{D N 7}$ ), the IIIP region, and the extracellular end of the IIIS6 region. Furthermore, a heterozygote of the $k d r$ and super-kdr mutations showed vastly increased resistance to insecticides, even though the $\mathrm{Na}^{+}$ channel is a monomer. Also, the para ${ }^{D N 7}$ aligns with a residue that causes paramyotonia congenita in the human SCN4A channel. An adjacent position in the human SCN5A mutation causes one form of LQT syndrome. The para $^{t s l}$ mutation aligns with one causing the jolting phenotype in mouse neuronal $\mathrm{Na}^{+}$channel. These insecticide-resistance mutations thus emphasize the S4-S5 loop, which is thought to comprise part of the receptor for the inactivation flap; therefore these mutations are themselves suspected to involve inactivation. Because the insecticides in question also interfere with inactivation, the suggestion that the mutations described here "may confer resistance by causing functional changes in sodium channel properties that compensate for, or alleviate the consequences of exposure to the insecticide" is attractive (Pittendrigh et al 1997). Another, independently

discovered pyrethroid resistance allele, a Val-to-Met mutation in IS6 (Park et al 1997), could also distort inactivation. 


\section{Changes in Regulation or Trafficking: Liddle Syndrome Caused by Epithelial $\mathrm{Na}^{+}$Channels}

Liddle syndrome is a hereditary form of human hypertension (pseudoaldosteronism). Although Liddle syndrome occurs in intestinal epithelia, we describe it here because neuroscientists may wish to be aware that it represents a striking paradigm for a gain-of-function mechanism. A series of mutations leading to an increased cell-surface expression of the epithelial amiloride-sensitive $\mathrm{Na}^{+}$channel $(\mathrm{ENaC})$ protein have been identified in Liddle syndrome patients. In contrast to other forms of hypertension, little or no circulating aldosterone and mineralocorticoids are found in the patients' plasma, but pathologically low plasma $\mathrm{K}^{+}$ (hypokalemia) indicates that the nephron is conducting excessive $\mathrm{Na}^{+}$and water reabsorption, which is indirectly coupled to $\mathrm{K}^{+}$secretion (Lifton 1995).

While this trait was being mapped to a short segment of chromosome 16 , the $\beta$-subunit of $\mathrm{ENaC}$ was cloned and mapped to the same locus. $\mathrm{ENaC}$ is present in the epithelia of the airway, colon, kidney, and exocrine glands. It is composed of three subunits with an uncertain stoichiometry, possibly $\alpha 2 \beta \gamma$, or $\alpha 3 \beta 3 \gamma 3$; all subunits are required for maximal channel activity (Canessa et al 1993, 1994; Snyder et al 1998). A fourth subunit has also been described, but it is expressed only in testis and ovary. The putative transmembrane topology of all ENaC subunits describes two transmembrane domains flanking a long extracellular loop and the $\mathrm{N}$ and $\mathrm{C}$ terminus on the intracellular side.

A functional impairment in $\alpha \mathrm{ENaC}$ and $\beta \mathrm{ENaC}$ subunits results in pseudohypoaldosteronism I, a disease that is caused by severe salt wasting and hyperkalemia. Liddle disease, in contrast, derives from mutations in a 95-bp segment of the $\mathrm{C}$ termini of $\beta \mathrm{ENaC}$ and $\gamma \mathrm{ENaC}$. These mutations introduce premature stop codons or frameshifts. The resulting deletions from the tail of the encoded proteins cause gain-of-function by increasing the cell-surface expression of ENaC (Hansson et al 1995a,b; Snyder et al 1995). Based on the presence of two Cterminal recognition motifs, two alternative mechanisms are being explored to explain how mutant channels predominantly accumulate in the plasma membrane. First, the proline-rich sequence PPPXYXXL is similar to two different tyrosinebased internalization motifs in the low-density lipoprotein receptor and the transferrin receptor (Collawn et al 1990), and disruption of this sequence would consequently suppress channel internalization. Second, the same sequence also fits a recently defined PY motif (PPXY) that plays a role in protein-protein interactions by binding to WW domains of other proteins (Chen \& Sudol 1995). Such an interaction partner, which may control ENaC surface expression, has been identified in the epithelial protein Nedd4 using yeast-two-hybrid screens (Schild et al 1996, Staub et al 1996). Mutations in ENaC that cause Liddle's syndrome abolish the interaction with Nedd4. It was further suggested that Nedd4, which possesses a ubiquitin-ligase domain, may be responsible for transferring ubiquitin to $\mathrm{ENaC}$ and thus target the channel for degradation (Goulet et al 1998). Alternatively, Nedd4 may accelerate channel endocytosis through a C-terminal C2 
domain by connecting to clathrin-coated vesicles (Shimkets et al 1997). In both cases, disruption of the ENaC-Nedd4 interaction would interfere with a physiological control system in collecting duct epithelial cells, where the level of $\mathrm{Na}^{+}$ channel expression is negatively controlled by cytosolic $\mathrm{Na}^{+}$(Dinudom et al 1998).

\section{Induction of Apoptosis}

A fascinating hypothesis was proposed and tested, with some positive results about grim and reaper, two Drosophila genes thought to regulate caspases and therefore apoptosis. The amino-terminal domains of these channels bear homology to the Shaker ball and were therefore tested as inactivation balls. They do indeed enhance the inactivation of Shaker channels, and they cause stable inactivation, which suggests that Reaper and Grim may participate in initiating apoptosis by stably blocking $\mathrm{K}^{+}$channels, depolarizing the cells, and therefore allowing $\mathrm{Ca}^{2+}$ entry (Avdonin et al 1998).

\section{SILENCING VIA INCREASED K ${ }^{+} \mathrm{OR} \mathrm{CL}^{-}$ CHANNEL FUNCTION}

\section{egl-36}

The $C$. elegans genome encodes some $80 \mathrm{~K}^{+}$channels, and egl-36 is the first of an anticipated large number of gain-of-function mutations in ion channels (Elkes et al 1997, Johnstone et al 1997). The egl-36 gene product is a noninactivating voltage-gated $\mathrm{K}^{+}$channel homologous to the vertebrate Kv3 family. There are semidominant alleles in the cytoplasmic $\mathrm{N}$-terminal tetramerization domain (Gluto-Lys) and in the S6 transmembrane domain (Pro-to-Ser). Both alleles shift the activation of the channels to more negative potentials than for wild type; this was surprising because neither region had previously been implicated in activation mechanisms. Both alleles decrease the excitability of the egg-laying and defecation muscles by preventing action potential initiation, and dominant-negative egl-36 mutations increase excitability by decreasing channel function. Null mutations have no observable phenotype.

\section{Gene Transfer of $\mathrm{K}^{+}$or $\mathrm{Cl}^{-}$Channels}

Several investigators have realized that gene transfer of ion channels, either acutely or via transgenic animals, is a gain-of-function strategy that could be used to manipulate cell excitability. In sympathetic ganglia, $\mathrm{ClC}-2 \mathrm{Cl}^{-}$channels expressed with an adenoviral vector change $\mathrm{E}_{\mathrm{Cl}}$ and, therefore, convert GABA synaptic potentials to become inhibitory (Staley et al 1996), and adenoviral expression of an inducible Kir2.1 construct causes inducible silencing (Johns et al 1999). In hippocampal neurons, adenovirus-expressed GIRK (Kir3.1/3.2) chan- 
nels cause agonist-induced silencing (Ehrengruber et al 1997), and lentivirus expression of Kir1.1 also silences neurons (Nadeau et al 1999).

A recent overexpression result reminds us that increases in $\mathrm{K}^{+}$channel function can in turn lead to altered expression of related channels. Mice overexpressing a Kv1.1 subunit, driven by a ubiquitous promoter, down-regulate the expression of other Kv1 channels, exhibit spontaneous electroencephalogram discharges, and have a reduced threshold for epileptiform discharge in hippocampal slices (Sutherland et al 1999).

\section{CHANNEL MUTANTS IN CARDIAC LONG-QT SYNDROME}

In the human heart, certain relatively rare congenital forms of hyperexcitability are caused by a delayed repolarization of the cardiac action potential. This dysfunction is reflected by an unusually prolonged Q-T interval in the electrocardiogram. LQT syndrome patients suffer from syncope and seizures and have an increased risk of sudden death when ventricular arrhythmias (torsades de pointes) progress to ventricular fibrillation. Although similar in diagnosis, the inherited forms of the LQT syndrome represent a genetically disparate collection of disorders. What has previously been addressed as $(a)$ sporadic LQT syndrome, (b) autosomal dominant Romano-Ward syndrome (LQT1-LQT6), and (c) autosomal recessive Jervell and Lange-Nielsen syndrome (JLN1-2) in fact is caused by a variety of mutations in the genes of five different cardiac ion channels: the voltage-gated potassium channel KvLQT1 (KCNQ1) (Wang et al 1996), the human $\mathrm{K}^{+}$channel related to Drosophila ether-a-go-go channels HERG (KCNH2) (Curran et al 1995), a sodium channel $\alpha$ subunit (SCN5A) (Wang et al 1995b), and the auxiliary $\mathrm{K}^{+}$channel subunits $\operatorname{minK}$ (KCNE1) (Splawski et al 1997) and MiRP1 (KCNE2) (Abbott et al 1999).

We present the channel mutations involved in LQT syndrome before discussing those of the epilepsies, because to a large extent understanding of the LQT syndrome can be understood "simply" by the molecular ion channel correlates of the various cardiac action potential phases, with little need to invoke compensatory changes in gene expression, alternative channel assembly, and the other factors that complicate epilepsy. A prolonged action potential could arise either (a) from defective $\mathrm{K}^{+}$channels normally responsible for the early and late phase of repolarization or $(b)$ from $\mathrm{Na}^{+}$and $\mathrm{Ca}^{2+}$ channels that open during the rapid depolarization and plateau phase and do not inactivate properly.

\section{SCN5A (LQT3)}

In 1995, Wang et al (1995b) showed that the rare LQT3 syndrome that mapped to chromosomal locus 3p21-24 was due to a three amino-acid deletion in the cytoplasmic linker between domains III and IV of the cardiac $\mathrm{Na}^{+}$channel $\alpha$ 
subunit SCN5A. This linker domain is partially responsible for channel inactivation, and when mutated in the equivalent skeletal muscle $\alpha$ subunit, SCN4A causes paramyotonia congenita or potassium-aggravated myotonia. In singlechannel recordings from the mutant expressed in Xenopus oocytes, the $\triangle \mathrm{KPQ}$ deletion mutant $S C N 5 A$ channels fluctuate between normal and noninactivating gating modes, which in vivo are expected to result in a small fraction of persistent, depolarizing $\mathrm{Na}^{+}$current during the plateau phase of the cardiac action potential (Bennett et al 1995). A similar current imbalance of the plateau phase may derive from single-codon mutations. Some of these point mutations produce $\mathrm{Na}^{+}$channels with increased $p_{\text {open }}$, altered voltage dependence, or decreased inactivation rates (Wang et al 1996, Dumaine \& Kirsch 1998). Another point mutation changes the interaction with $\beta_{1} \mathrm{Na}^{+}$channel subunits (An et al 1998). Other missense mutations in SCN5A, one of which causes the channels to recover from inactivation more rapidly than normal, cause a group of cardiac malfunctions allelic to LQT3 and classified as idiopathic ventricular fibrillation (Chen et al 1998).

\section{Potassium Channels}

KVLQT1/minK (LQT1/5) In the late phase of rapid repolarization (phase 3) of the ventricular action potential, the delayed rectifier $\mathrm{K}^{+}$current that counterbalances the calcium currents is a sum of two different currents: $I_{\mathrm{Kr}}$, the more rapidly activating $\mathrm{K}^{+}$current, which has an inwardly rectifying $\mathrm{I} / \mathrm{V}$ profile and is sensitive to class III antiarrhythmics; and $I_{\mathrm{Ks}}$, the slowly activating $\mathrm{K}^{+}$current, which has a linear voltage dependence (Sanguinetti \& Jurkiewicz 1990). The slow voltagegated $I_{\mathrm{Ks}}$ channels are perfectly reconstituted from the association of two different proteins, a poreforming $\alpha$-subunit KVLQT1 (KCNQ1) and the single-helix $\beta$-subunit minK or IsK (KCNE1) (Barhanin et al 1996, Sanguinetti et al 1996). Using positional cloning, various mutations were found in KVLQT1 of patients with chromosome 11p15.5-linked LQT1 (Wang et al 1996) or the JLN syndrome that is associated with bilateral deafness (Neyroud et al 1997). Of those, several mutants exert a dominant-negative effect on the tetrameric $\mathrm{K}^{+}$channel assembly, whereas others may result in altered $\mathrm{K}^{+}$selectivity (Wollnik et al 1997) (see also $K C N Q 2 / 3$ ) and in permeability and thus impaired channel activity (Ackerman et al 1998). Mutations in minK occur both in families with chromosome 21q22.1linked LQT5 and in JLN2 (Schulze-Bahr et al 1997, Tyson et al 1997). Mice with a disrupted minK display JLN-like inner-ear defects (Vetter et al 1996). Functional characterization revealed that the mutated $\beta$-subunit in LQT5 reduced $I_{\mathrm{Ks}}$ by shifting the voltage dependence of channel activation and accelerating the rate of channel deactivation.

HERG (LQT2) At the same time, HERG (KCNH2), the $\mathrm{K}^{+}$channel gene related to the Drosophila gene encoding the ether-a-go-go $\mathrm{K}^{+}$channel (Warmke \& Ganetzky 1994), was identified as underlying $I_{\mathrm{Kr}}$ and also causing the LQT2 form mapped to chromosome 7q35-36. Two intragenic deletions, one splice- 
donor mutation, and three missense mutations originally identified (Curran et al 1995) together with other mutations (Benson et al 1996) provide a spectrum of channel defects that include lack of expression, dominant-negative effects, and altered voltage dependence of activation and inactivation (Sanguinetti et al 1996, Chen et al 1999, Zhou et al 1998). From its primary amino-acid sequence, HERG is classified as a voltage-gated $\mathrm{K}^{+}$channel. However, when reconstituted by itself [and together with MiRP1 (Abbott et al 1999)], HERG is functionally "inverted," i.e. it carries little outward current during maintained depolarization but large inward current during repolarization, much like $I_{\mathrm{Kr}}$ (Sanguinetti et al 1995, Trudeau et al 1995). This behavior of HERG would be satisfactorily explained if the rates of channel activation and inactivation were reversed (Schonherr \& Heinemann 1996, Smith et al 1996). The decreases in HERG current caused by all mutations studied to date seem sufficient to explain the decrease in $I_{\mathrm{Kr}}$ and subsequent prolonged QT interval.

Some LQT syndrome genes remain to be isolated. In addition to a possibly X-linked LQT syndrome (LQT6?), a gene locus for another LQT syndrome (LQT4) has been linked to chromosome 4q25-27 (Schott et al 1995).

\section{CHANNEL MUTANTS IN EPILEPSY}

One may consider the recurrent spontaneous disturbances of electrical activity and hyperexcitability states in neuronal networks typical of all forms of epilepsy a "gain-of-function" disorder in the broader sense. In central nervous system neurons, the fine balance of the activities of $\mathrm{Na}^{+}, \mathrm{Ca}^{2+}$, and $\mathrm{K}^{+}$channels determine whether the cells are silenced or enter an uncontrolled bursting mode typical of epileptic behavior. Although epilepsies are a heterogeneous group of disorders and their inheritance $(\sim 50 \%)$ may be complex, a series of channelopathies that result in alteration of ion flux, channel regulation, or expression have now been recognized as causes of changes in neuronal excitability that generates epilepsy. Autosomal dominant nocturnal frontal-lobe epilepsy (ADNFLE) has already been discussed above in the context of possible neuronal nicotinic acetylcholine (nAChR) receptor gain-of-function diseases.

\section{Potassium Channels}

$K C N Q 2 / 3$ Because they are responsible for repolarizing the nerve cell and stabilizing the resting potential after an action potential has been fired, dysfunctional $\mathrm{K}^{+}$channels have long been sought as the cause of hyperexcitability and abnormal electrical discharge in the brain. It was shown only recently, however, that two members of a novel $\mathrm{K}^{+}$channel subfamily, $K C N Q 2$ and $K C N Q 3$, cause benign familial neonatal convulsions (BFNC), a rare syndrome (Biervert et al 1998, Charlier et al 1998, Singh et al 1998, Yang et al 1998). This generalized neurological disorder is characterized by frequent short seizures that begin on 
days 2-4 of life, with spontaneous remission usually occuring within a few weeks and a recurrence of seizures in $10-15 \%$ of the patients.

Structurally, both $K C N Q 2$ and $K C N Q 3$ are characterized by six transmembrane regions typical of $\mathrm{Kv}$ channels and show highest sequence identity to KvLQT1 (gene renamed $K C N Q 1$ ), the cardiac $\mathrm{K}^{+}$channel mutated in one autosomal dominant form of LQT syndrome (see above). When expressed individually in Xenopus oocytes, both cRNAs give rise to small $\mathrm{K}^{+}$outward currents with similar voltage dependence and kinetics. Following coexpression of the two subunits, macroscopic current amplitudes are potentiated by at least one order of magnitude. Unlike $K C N Q 1$, which requires an auxiliary $\beta$-subunit, $\operatorname{minK}(K C N E 1)$, to form robust $\mathrm{K}^{+}$currents in the heart, the brain $K C N Q 2$ and $K C N Q 3$ channels are not affected by $\operatorname{minK}$ (or $K C N Q 1$ ) coexpression.

Positional cloning and chromosomal mapping showed $K C N Q 2$ and $K C N Q 3$ located at 20q13.3 (Biervert et al 1998, Singh et al 1998) and 8q24 (Charlier et al 1998), respectively, the two known loci for BFNC. In families affected by BFNC, only one mutation, a glycine replacement for valine in the highly conserved $\mathrm{P}$ region, has been detected in $K C N Q 3$. In contrast, seven truncation, frameshift, missense, splice-site mutations and a deletion have been found in both the cytoplasmic ends as well as in the core region of $K C N Q 2$; these mutations might result in dysfunction, in a gain-of-function, or in a dominant-negative effect (Keating \& Sanguinetti 1996, Stoffel \& Jan 1998). In heterologous expression systems, channel function was partially or completely abolished in various mutant channels. KCNQ2 and $K C N Q 3$ subunits coimmunoprecipitate (Schroeder et al 1998 ) and presumably coassemble in the brain as heterotetramers, in analogy to several $\mathrm{Kv}$ and Kir channels. It is interesting that when either $K C N Q 2$ or $K C N Q 3$ carrying pore region mutations were mixed with wild-type subunits in ratios mimicking the situation of a heterozygous patient in a dominant disease, macroscopic currents were reduced by at most 20-30\% (Schroeder et al 1998), indicating that the tested BFNC mutations did not exert a dominant-negative effect.

The mRNAs of $K C N Q 2$ and $K C N Q 3$ display a generally overlapping expression pattern in the adult brain, with strong signals mainly in the neocortex, cerebellum, and hippocampus, brain structures that are susceptible to epileptic seizures (Tinel et al 1998, Wang et al 1998). In the context of the age-dependent change in the frequency of convulsions in BFNC patients, it is interesting to note that during development (at least in rats), different association profiles of $K C N Q 2$ and $K C N Q 3$ subunits may occur: $K C N Q 3$ is expressed at very low amounts at birth when $K C N Q 2$ is already expressed at prominent levels.

Although mutated $K C N Q$ channels display surprisingly small loss of function, the physical interaction of $K C N Q 2$ and $K C N Q 3$, their overlapping distribution, and the presence of mutations in BFNC patients indicate that BFNC is caused by a reduced function or number of this channel species. In contrast to the heart, where the association of $K C N Q 1$ with $\operatorname{minK}$ results in the well-known phase 3 $I_{\mathrm{ks}}$ currents that provide the repolarizing counterbalance for the action of activated calcium channels, the functional correlate of the $K C N Q 2 / 3$ heteromulti- 
meric channels was revealed only recently. In comparisons among the molecular and $\mathrm{K}^{+}$current profiles of peripheral sympathetic neurons that differed distinctly in their firing patterns, it became clear that the less-active neurons expressed $K C N Q 2 / 3$ subunits as well as very prominent M currents (Wang et al 1998). These slowly activating and deactivating currents were the first voltage-gated currents in vertebrate neurons found to be under synaptic control: They are inhibited by several G protein-coupled receptors and are critical in determining the subthreshold excitability of neurons (Adams \& Brown 1982, Adams et al 1982). A detailed comparison of the biophysical and pharmacological properties of native currents with heterologously expressed $K C N Q 2 / 3$ subunits, as well as the subunit expression pattern, provided good evidence that $K C N Q 2 / 3$ channels are indeed the molecular correlate of the M current.

KCNQ4 A fourth member of this $\mathrm{K}^{+}$channel subfamily, $K C N Q 4$, with 37-44\% amino acid identity to other $K C N Q$ members, has recently been isolated from man and found expressed at high levels in the cochlea. Its gene has been mapped to 1p34 together with DFNA2, a locus for dominant progressive hearing loss (Kubisch et al 1999). In a screen of 45 families with autosomal dominant deafness, a $K C N Q 4$ missense mutation that affects the first glycine in the highly conserved GYG signature sequence of the $P$ region was found in one French pedigree. Recall that mutations at the aligning positions also change the ion selectivity (Kir3.2 channels in the weaver mouse) or abolish channel function (KCNQ1 in LQT syndrome) (Russell et al 1996, Wollnik et al 1997). Mutated KCNQ1 subunits exert a dominant-negative effect when coexpressed with wild-type subunits. Mutant KCNQ4G285S channels when expressed in Xenopus oocytes also failed to yield detectable currents and had a dominant-negative effect with wild-type $K C N Q 4$ and $K C N Q 3$ subunits. Thus, dysfunctional $K C N Q 4$ may cause the progressive malfunction of outer hair cells and hearing loss in DFNA2.

KCNA1: Episodic Ataxia Type 1 Associated with Epilepsy Various mutations in $K C N A 1$, the gene that encodes the poreforming subunit of voltage-dependent Kv1.1 channels, account for episodic ataxia, a rare familial neurological disorder in which individuals suffer from attacks of generalized ataxia and myokymia (Browne et al 1994, Adelman et al 1995). Mice with disrupted Kv1.1 subunits display frequent spontaneous seizures postnatally (Smart et al 1998), and other recent reports suggest that episodic ataxia type 1 (Spauschus et al 1998, Zuberi et al 1999) is also associated with partial epilepsy in humans.

\section{Cacna1A Ca ${ }^{2+} \alpha_{1 \mathrm{~A}}$ Subunits: Absence Epilepsy in Tottering Mice}

Several mouse mutants, including mocha, slow-wave epilepsy, stargazer (waggler), and tottering (leaner), display symptoms resembling petit mal or absence seizures in humans: infrequent spontaneous motor seizures and a recurrent behav- 
ioral arrest with a fixed staring posture that is accompanied by generalized spikewave discharges. In tottering, positional cloning localized the gene CacnalA, encoding the $\alpha_{1 \mathrm{~A}}$ poreforming subunit of $\mathrm{P} / \mathrm{Q}$-type $\mathrm{Ca}^{2+}$ channels, within $<0.07$ $\mathrm{cM}$ from the $\mathrm{tg}$ locus on mouse chromosome 8 (Fletcher et al 1996). A single nucleotide exchange results in a nonconservative amino acid change near the second $\mathrm{P}$ region. A more severe CacnalA allele, leaner $\left(t g^{\mathrm{la}}\right)$, which also shows absence seizures, severe ataxia, and often fails to survive weaning, contains a mutated splice donor consensus site that results in the truncation of the normal open reading frame and expression of altered C-terminal sequences. mRNA expression patterns of the $\alpha_{1 \mathrm{~A}}$ subunit show wide expression in mouse brain, with strong levels in the olfactory bulb, cerebral cortex, hippocampus, inferior colliculus, and cerebellum. Yet the $t g$ phenotype appears remarkably restricted, with aberrant synaptogenesis in the locus coeruleus and cellular degeneration in the cerebellum. In leaner, the apoptotic cell death in cerebellar granule cells and Purkinje cells is consistent with the ataxic phenotype and with 60-65\% decreased P-type currents in Purkinje cells; this decrease is slightly greater than for tottering (Lorenzon et al 1998, Wakamori et al 1998). This dysfunction suggests that decreased intracellular $\mathrm{Ca}^{2+}$ levels help to cause degeneration. There is also evidence that $\mathrm{L}$-type $\mathrm{Ca}^{2+}$ channel $\alpha 1 \mathrm{C}$ subunit mRNA expression is up-regulated in the Purkinje cells of tottering mice (Campbell \& Hess 1999), so that functional modulation by alternative $\alpha$ isoforms or other auxiliary and differentially expressed subunits may account for the observed cellular specificity of the $t g$ mutation. It is unclear how these molecular changes of low-threshold $\mathrm{Ca}^{2+}$ channels alter neuronal network properties, e.g. in thalamocortical circuits, to trigger absence seizures.

\section{Auxiliary Subunits}

Cacnb4 $\mathrm{Ca}^{2+} \boldsymbol{\beta}_{4}$ Subunits: Spike-Wave Epilepsy in Lethargic Mice Three examples of inherited ion channel diseases, two in mice and one in humans, have been reported in which epileptic seizures result not from a dysfunction of the poreforming $\alpha$-subunits but from mutations in regulatory channel subunits: the Cacnb4 $\mathrm{Ca}^{2+}$ channel $\beta_{4}$ subunit (lethargic), the Cacng2 $\mathrm{Ca}^{2+}$ channel $\gamma$ subunit (stargazer), and the $S C N 1 b \mathrm{Na}^{+}$channel $\beta_{1}$ subunit $\left(\mathrm{GEFS}^{+}\right.$).

$\mathrm{Ca}^{2+}$ channels with more-or-less-complete function are reconstituted from at least three subunits, $\alpha_{1}, \alpha_{2} \delta$, and $\beta$ (a fourth subunit, $\gamma$, is associated with skeletal muscle $\mathrm{Ca}^{2+}$ channels; see below), and all of the four cytoplasmic $\beta$ subunits $\left(\beta_{1}-\beta_{4}\right)$ identified so far may function as modulators of current amplitude, kinetics, and voltage dependence. The $\beta$ subunit interacts with the intracellular I-II linker of the pore-forming $\alpha_{1}$-subunit via a conserved 30-amino acid stretch (Pragnell et al 1994). When Cacnb4, the gene that encodes the $\beta_{4}$ subunit, was comapped on mouse chromosome 2 with the locus for the neurological mutation lethargic $(l h)$, a positional candidate approach was used to determine whether mutated $\beta_{4}$ was responsible for the ataxia in $l h$ mice. Homozygotic $l h$ mice can 
be recognized not only by their ataxic and lethargic behavior, but also by the spontaneous motor seizures and the generalized cortical spike-wave discharges that commence 2-3 weeks after birth and resemble petit mal seizures in humans. Burgess et al (1997) discovered in their genomic analysis that a 4-bp insertion into the splice donor site of the intron between exons 5 and 6 resulted in exon skipping, translational frameshift, and $>60 \%$ of C-terminal protein truncation with a loss of the essential $\beta_{4}-\alpha_{1}$ interaction site. The reduced abundance of the Cacnb4 transcripts in $l h / l h$ brains and the severe neurological symptoms suggest an important role for the $\beta_{4}$ subunits in $\mathrm{Ca}^{2+}$ channel control of neuronal excitability. How might the hyperexcitability states connected to the generalized epileptic phenotype arise in $/ h$ mice? In important clues, McEnery et al (1998) reported increased levels of $\beta_{1 \mathrm{~b}}$ subunits and $\alpha_{1 \mathrm{~B}} \beta_{1 \mathrm{~b}}$ complexes in $\mathrm{lh}$ mice, and Burgess et al (1999) confirmed this and also reported increased levels of $\alpha_{1 \mathrm{~B}} \beta_{2}$ and $\alpha_{1 \mathrm{~B}} \beta_{3}$ complexes. This phenomenon was termed subunit reshuffling by Burgess et al (1999) and would be expected to lead to functional differences in $\mathrm{Ca}^{2+}$ channel currents because previous heterologous expression experiments showed that the detailed properties of $\mathrm{Ca}^{2+}$ channels are influenced by the nature of the $\beta$ subunit. There were, however, no detectable changes in the amplitude, kinetics, voltage dependence, and pharmacology of $\mathrm{Ba}^{2+}$ currents through $\mathrm{Ca}^{2+}$ channels in Purkinje cells of 14- to 19-day-old $l h / l h$ and wild-type mice (Burgess et al 1999). Nevertheless, one presumes that a cell type(s), age(s), or other condition(s) will be found in which the unusual $\alpha_{1} \beta$ complexes do affect $\mathrm{Ca}^{2+}$ channel properties, thus explaining the pathophysiology of the $l h$ phenotype.

Cacng2 $\mathrm{Ca}^{2+}$ y Subunits: Absence Epilepsy in Stargazer In stargazer (stg) mouse mutants, named for the distinctive head tossing, highly frequent and prolonged spike-wave seizures can be recorded when the animal is still-typical of absence epilepsy. Analysis of a physical contig critical to stargazer revealed an early transposon insertion into intron 2 of the stargazer gene that likely results in inefficient splicing or premature transcriptional termination (waggler shows an analogous effect in intron 1). The open reading frame encodes a protein (stargazin) that spans the plasma membrane four times, with highest similarity to the $\gamma$ subunit of skeletal muscle voltage-gated $\mathrm{Ca}^{2+}$ channel (Jay et al 1990, Letts et al 1998), but 100 amino acids longer at the $C$ terminus. Given the structural similarity to the auxiliary skeletal muscle $\gamma$ subunits, Letts et al (1998) investigated whether stargazin (later named Cacng2), which is expressed solely in the brain, modifies the properties of neuronal voltage-dependent $\mathrm{Ca}^{2+}$ channels. When expressed in a stable BHK cell line, stargazin slightly shifted the voltage dependence of channel availability to more hyperpolarizing potentials, possibly by stabilizing channel inactivation. The combined evidence strongly suggests that stargazin represents the first $\gamma$ subunit for neuronal $\mathrm{Ca}^{2+}$ channels and that its effect on channel gating plays an essential role in the inhibition of presynaptic $\mathrm{Ca}^{2+}$ entry. In stargazer mutants, therefore, too much $\mathrm{Ca}^{2+}$ might enter the cell. Perhaps pathological intracellular $\mathrm{Ca}^{2+}$ levels also play a role in the granule-cell- 
specific loss of brain-derived neurotrophic factor expression (Qiao et al 1996) and in the defects of classical eyeblink conditioning, a form of sensorimotor learning that depends on the cerebellum (Qiao et al 1998). An exciting challenge will be to explain how the improperly assembled $\mathrm{Ca}^{2+}$ channels produce the decreased spike threshold, increased pacemaker current, and other aspects of increased excitability in stargazer cortical neurons (DiPasquale et al 1997).

SCN1B Na ${ }^{+}$Channel $\beta_{1}$ Subunit $\left(\mathrm{GEFS}^{+}\right)$In voltage-gated $\mathrm{Na}^{+}$channels, the large pore-forming subunit forms functional channels by itself, but it is modulated in gating and expression levels by two smaller $\beta_{1}$ and $\beta_{2}$ subunits, integral membrane proteins consisting of a single transmembrane region (Isom et al 1992). The $\mathrm{Na}^{+}$channel $\beta_{1}$ subunit $(S C N 1 B)$ is expressed in brain, skeletal muscle, and heart and has been localized to human chromosome 19q13.1. As revealed recently by linkage analysis, this site is a locus for generalized epilepsy with febrile seizures plus $\left(\mathrm{GEFS}^{+}\right.$) (Wallace et al 1998). Patients have a range of seizure phenotypes, including febrile seizures in early childhood and afebrile generalized convulsions with poor prognosis continuing beyond the age of six. A mutation screen for $S C N 1 B$ in eight genotyped individuals with stringent criteria for "febrile seizures plus" identified a mutation that changes a conserved cysteine residue in the extracellular $\mathrm{N}$ terminus and disrupts a putative disulfide bridge that normally maintains an immunoglobulin-like fold. From earlier functional studies it was clear that an intact $\beta_{1}$ subunit accelerates $\mathrm{Na}^{+}$channel inactivation to the range seen in normal neurons (Krafte et al 1990, Isom et al 1992). Indeed, coexpression in Xenopus oocytes of the mutant $S C N 1 B$ with the rat brain $\mathrm{Na}^{+}$channel $\alpha$ subunit RBII revealed that the mutant $\beta_{1}$ subunits failed to accelerate the time course of inactivation and recovery from inactivation as observed for wild-type $\beta_{1}$ subunits (Wallace et al 1998). Thus, the loss-of-function $S C N 1 B$ allele is predicted to cause persistent inward $\mathrm{Na}^{+}$currents in neurons, resulting in delayed repolarization and hyperexcitability.

\section{GAIN-OF-FUNCTION MUTATIONS IN G PROTEIN- COUPLED RECEPTORS}

The signaling cascade that connects $G$ protein-coupled receptors, $G$ proteins, and effector proteins commences with ligand stimulation of the receptor and is terminated by the intrinsic GTPase activity of the G $\alpha$ subunit. Each of the components involved acts as a switch for the G protein cycle, and some pathological changes that disrupt their function are predicted to render the system resistant to receptor stimulation. Hyperfunction, on the other hand, is likely to result when a component is turned on without receptor activation or when the proteins remain in the on state for too long. In the past few years, a series of mutations in $G$ protein-coupled receptors that disrupt (loss of function) or increase (gain of function) receptor function have been described to cause characteristic hereditary 
diseases in humans and have been summarized in various excellent reviews (Birnbaumer 1995; Shenker 1995; Rao \& Oprian 1996; Spiegel 1996, 1997; Scheer \& Cotecchia 1997), as well as in two convenient online databases (http://tinyGRAP.uit.no/queryform7.html and http://www.gpcr.org/7tm/). Here we briefly discuss exemplar gain-of-function mutations.

\section{Retinitis Pigmentosa and Stationary Congenital Night Blindness}

A series of both naturally occurring and directed man-made mutations have been described to cause constitutive activation in the human visual pigment rhodopsin. A single point mutation in transmembrane region 7 of rhodopsin in retinal rod photoreceptors, where a lysine residue at position 296 is replaced by a glutamate, supplies insight into the possible mechanisms of constitutive receptor activation (Robinson et al 1992). Autosomal dominant retinitis pigmentosa, the most common inherited disease of the visual system, results in a severe degeneration of the retinal pigment epithelium. Mutation of Lys296 in autosomal dominant retinitis pigmentosa causes the loss of the salt bridge between transmembrane domains 3 and 7 and disrupts the coupling to the light-sensitive chromophore 11-cis retinal, which is normally bonded covalently to this site by a Schiff base. Under physiological conditions temporary disruption of this salt bridge is caused when 11cis retinal isomerizes into all-trans retinal following light absorption. With Lys296 mutated to glutamate, the "empty" rhodopsin mimics the activated state of the receptor and may activate transducin even in the dark. As expected, mutation of the other Schiff base counterion, Glu113 in transmembrane region 3, leads to the same form of constitutive activation. How the constitutively active rhodopsin causes rod photoreceptor degeneration is still under debate and may include altered receptor phosphorylation by rhodopsin kinase and arrestin binding (Rao \& Oprian 1996).

Two other gain-of-function mutations in rhodopsin cause congenital night blindness, a comparatively benign disorder in which patients have difficulty seeing under dim light conditions but do not suffer from progressive retinal degeneration. Both mutations, Gly90Asp and Ala292Glu, in the second and seventh transmembrane region place a negatively charged residue in the vicinity of Lys296, which competitively interact with and weaken the salt bridge between transmembrane segments 3 and 7 (Dryja et al 1993, Rao et al 1994). Thus, although retinal is bound efficiently, the cells adapt to the apparent light signal generated by the mutant receptors and desensitize until they no longer respond to light.

\section{Familial Male Precocious Puberty and Thyroid Adenomas}

By using recombinant $\alpha_{1 \mathrm{~B}}$ adrenergic receptors it was demonstrated that replacement by any other amino acid of unique residues in the third intracellular loop 
structure adjacent to helix 6 shifts the receptor from an inactive to an active conformational state in the absence of receptor ligand (Cotecchia et al 1990, Allen et al 1991, Kjelsberg et al 1992). Subsequently, similar somatic mutations in the receptors for the pituitary glycoprotein hormones thyrotropin (TSH) (Asp619Gly and Ala623Ile) (Parma et al 1993) and luteinizing hormone (LH) (Gly578Asp) (Shenker et al 1993) were recognized to constitutively activate adenylate cyclase, to raise intracellular levels of cyclic AMP, and thus to cause severe hyperfunction in the endocrine system. TSH in the thyroid gland controls cellular differentiation and growth of thyrocytes and induces the release of thyroid hormones. LH induces the testicular Leydig cells to develop and release testosterone, which in turn regulates spermatogenesis and virility in men. Hence, the observed serious consequences of constitutively active TSH and LH receptors are obvious. Hyperfunctional TSH receptors induce tissue hyperplasia and hyperthyroidism in patients with thyroid adenomas. Similarly, elevated testosterone levels caused by hyperactive LH receptors induced puberty by age 4 in affected children from eight families, even with prepubertal levels of gonadotropins. In the latter case, it is easily explained why only young male children develop this autosomal dominant form of precocious puberty: In contrast to the Leydig cells, where LH is sufficient to trigger steroidogenesis, ovaries require costimulation of LH and follicle-stimulating hormone for progesterone/estrogen production; thus inappropriately activated LH receptors alone do not cause familial male precocious puberty in females.

\section{RNA Editing of a G Protein-Coupled Receptor}

The most complete study of RNA editing at a $\mathrm{G}$ protein-coupled receptor concerns the serotonin 5- $\mathrm{HT}_{2 \mathrm{C}}$ receptor (Burns et al 1997, Niswender et al 1999). This receptor is edited at five or more positions in rat, mouse, and human tissue. Some of the editing events occur within the second intracellular loop, crucial for $\mathrm{G}$ protein coupling. The Vanderbilt group has now shown that the editing both decreases the potency of 5-HT (Burns et al 1997) and decreases the extent of spontaneous activity of the receptor (Niswender et al 1999). Several of the unedited RNA species, which would represent gain-of-function mutations, do exist in tissue (Burns et al 1997).

\section{CONCLUSIONS}

We are impressed that most presently known, naturally occurring, molecular gainof-function mutations occur in regions of channels and receptors that were previously investigated in some detail by site-directed mutagenesis and heterologous expression. Examples include the $\mathrm{P}$ region of the $\mathrm{K}^{+}$channel pore, the $\mathrm{M} 2$ region of nicotinic receptor subunits, the several regions in the $\alpha$ subunit responsible for inactivation of $\mathrm{Na}^{+}$channels, the subunits of $\mathrm{Na}^{+}$channels, and TM6 of G protein-coupled receptors. [Other gain-of-function diseases do, indeed, occur in 
more surprising regions of channels (Wang et al 1995a)]. In few or no cases did the original biophysical and biochemical investigators suggest that the designed mutations actually underlie an inherited disease.

This situation is changing. In 1995 through 1997, the unusual gating properties of the HERG channels were explored in structure/function studies after they were identified as the cause of one LQT subtype. Although genes for the proteins of membrane excitability were formerly identified via biochemistry, toxin binding, or expression cloning, they are now often identified via genome surfing and positional cloning. The power of molecular genetics has also led to a large literature, including a chapter in this series (McGue \& Bouchard 1998), on the possible relationship between psychiatric diseases or personality traits on the one hand, and polymorphisms in the genes for excitability proteins on the other. These polymorphisms occur in both coding and regulatory regions and extend to the dopamine, serotonin, $\mathrm{GABA}_{\mathrm{A}}$ receptors, to a nicotinic receptor (Leonard et al 1998), to $\mathrm{Ca}^{2+}$-activated $\mathrm{K}^{+}$channels (Chandy et al 1998; but see Stober et al 1998), and to the serotonin transporter (Malhotra \& Goldman 1999).

Psychiatric diseases, like most epilepsies, are both polygenic and multifactorial. It is therefore worth stressing that despite the relatively straightforward explanations for hyperexcitability in LQT syndrome caused by channel mutants, there are no relatively complete explanations for epileptic states caused by channel or receptor mutants. Homeostatic mechanisms at many levels are being investigated to solve these problems. Neuroscience is sure to benefit from a resulting trend: Researchers primarily interested in the properties of excitable cells are working closely with those trained in clinical problems.

\section{ACKNOWLEDGMENTS}

We thank A Auerbach, NJM Birdsall, J Garcia-Anoveros, R Dingledine, AG Engel, F Lehmann-Horn, D Mackinnon, JL Noebels, RL Ruff, M Sanguinetti, W Shi, M Yuzaki, and our colleagues at Caltech and Göttingen for many comments. Preparation of this chapter was supported by the Alexander von Humboldt Foundation. Work in our laboratories on this topic is supported by National Institutes of Health grants GM29836, MH49176, and NS11756, by the California Tobacco-Related Disease Research Program, and by the Sidney Stern Foundation.

Visit the Annual Reviews home page at www.AnnualReviews.org.

\section{LITERATURE CITED}

Abbott GW, Sesti F, Splawski I, Buck ME, Lehmann MH, et al. 1999. MiRP1 forms $\mathrm{I}_{\mathrm{Kr}}$ potassium channels with HERG and is associated with cardiac arrhythmia. Cell 97:175-87
Ackerman MJ, Schroeder JJ, Berry R, Schaid DJ, Porter CJ, et al. 1998. A novel mutation in KVLQT1 is the molecular basis of inherited long QT syndrome in a near-drowning patient's family. Pediatr. Res. 44:148-53 
Adams CM, Anderson MG, Motto DG, Price MP, Johnson WA, et al. 1998a. Ripped pocket and pickpocket, novel Drosophila DEG/ENaC subunits expressed in early development and in mechanosensory neurons. J. Cell Biol. 140:143-52

Adams CM, Snyder PM, Price MP, Welsh MJ. 1998b. Protons activate brain $\mathrm{Na}^{+}$channel 1 by inducing a conformational change that exposes a residue associated with neurodegeneration. J. Biol. Chem. 273:30204-7

Adams PR, Brown D. 1982. Synaptic inhibition of the M-current: slow excitatory postsynaptic potential mechanism in bullfrog sympathetic neurones. J. Physiol. 332:26372

Adams PR, Brown DA, Constanti A. 1982. Pharmacological inhibition of the M-current. J. Physiol. 332:223-62

Adelman JP, Bond CT, Pessia M, Maylie J. 1995. Episodic ataxia results form voltagedependent potassium channels with altered functions. Neuron 15:1449-54

Allen LF, Lefkowitz RJ, Caron MG, Cotecchia S. 1991. G-protein-coupled receptor genes as protooncogenes: constitutively activating mutation of the $\alpha_{1 \mathrm{~B}}$-adrenergic receptor enhances mitogenesis and tumorigenicity. Proc. Natl. Acad. Sci. USA 88:11354-58

An RH, Wang XL, Kerem B, Benhorin J, Medina A, et al. 1998. Novel LQT-3 mutation affects $\mathrm{Na}^{+}$channel activity through interactions between $\alpha$ - and $\beta 1$-subunits. Circ. Res. 83:141-46

Avdonin V, Kasuya J, Ciorba MA, Kaplan B, Hoshi T, et al. 1998. Apoptotic proteins Reaper and Grim induce stable inactivation in voltage-gated $\mathrm{K}^{+}$channels. Proc. Natl. Acad. Sci. USA 95:11703-8

Babenko AP, Aguilar-Bryan L, Bryan J. 1998. A view of sur/KIR6.X, KATP channels. Annu. Rev. Physiol. 60:667-87

Barhanin J, Lesage F, Guillemare E, Fink M, Lazdunski M, et al. 1996. K(V)LQT1 and lsK (minK) proteins associate to form the $\mathrm{I}(\mathrm{Ks})$ cardiac potassium current. Nature 384:78-80
Bassilana F, Champigny G, Waldmann R, de Weille JR, Heurteaux C, et al. 1997. The acid-sensitive ionic channel subunit ASIC and the mammalian degenerin MDEG form a heteromultimeric $\mathrm{H}^{+}$-gated $\mathrm{Na}^{+}$channel with novel properties. J. Biol. Chem. 272:28819-22

Bennett PB, Yazawa K, Makita N, George AL Jr. 1995. Molecular mechanism for an inherited cardiac arrhythmia. Nature 376:683-85

Benson DW, MacRae CA, Vesely MR, Walsh EP, Seidman JG, et al. 1996. Missense mutation in the pore region of HERG causes familial long QT syndrome. Circulation 93:1791-95

Bertrand S, Devillers-Thiery A, Palma E, Buisson B, Edelstein SJ, et al. 1997. Paradoxical allosteric effects of competitive inhibitors on neuronal $\alpha 7$ nicotinic receptor mutants. NeuroReport 8:3591-96

Bertrand S, Weiland S, Berkovic SF, Steinlein OK, Bertrand D. 1998. Properties of neuronal nicotinic acetylcholine receptor mutants from humans suffering from autosomal dominant nocturnal frontal lobe epilepsy. Br. J. Pharmacol. 125:751-60

Bevan S, Yeats J. 1991. Protons activate a cation conductance in a sub-population of rat dorsal root ganglion neurones. J. Physiol. 433:145-61

Bhattacharyya BJ, Day JW, Gundeck JE, Leonard S, Wollmann RL, et al. 1997. Desensitization of mutant acetylcholine receptors in transgenic mice reduces the amplitude of neuromuscular synaptic currents. Synapse 27:367-77

Biervert C, Schroeder BC, Kubisch C, Berkovic SF, Propping P, et al. 1998. A potassium channel mutation in neonatal human epilepsy. Science 279:403-6

Birnbaumer M. 1995. Mutations and diseases of $\mathrm{G}$ protein coupled receptors. J. Recept. Signal Transduct. Res. 15:131-60

Browne DL, Gancher ST, Nutt JG, Brunt ER, Smith EA, et al. 1994. Episodic ataxia/ myokymia syndrome is associated with point mutations in the human potassium 
channel gene, KCNA1. Nat. Genet. 8:13640

Brusa R, Zimmermann F, Koh DS, Feldmeyer D, Gass P, et al. 1995. Early-onset epilepsy and postnatal lethality associated with an editing-deficient GluR-B allele in mice. Science 270:1677-80

Burgess DL, Biddlecome GH, McDonough SI, Diaz ME, Zilinski CA, et al. 1999. Subunit reshuffling modifies $\mathrm{N}$ - and P/Q-type $\mathrm{Ca} 2+$ channel subunit compositions in lethargic mouse brain. Mol. Cell Neurosci. 13:293-311

Burgess DL, Jones JM, Meisler MH, Noebels JL. 1997. Mutation of the $\mathrm{Ca}^{2+}$ channel $\beta$ subunit gene $C c h b 4$ is associated with ataxia and seizures in the lethargic (lh) mouse. Cell 88:385-92

Burns CM, Chu H, Rueter SM, Hutchinson LK, Canton H, et al. 1997. Regulation of serotonin-2C receptor G-protein coupling by RNA editing. Nature 387:303-8

Campbell DB, Hess EJ. 1999. L-type calcium channels contribute to the tottering mouse dystonic episodes. Mol. Pharmacol. 55:2331

Canessa CM, Horisberger JD, Rossier BC. 1993. Epithelial sodium channel related to proteins involved in neurodegeneration. Nature 361:467-70

Canessa CM, Schild L, Buell G, Thorens B, Gautschi I, et al. 1994. Amiloride-sensitive epithelial $\mathrm{Na}^{+}$channel is made of three homologous subunits. Nature 367:463-67

Cannon SC. 1996. Sodium channel defects in myotonia and periodic paralysis. Annu. Rev. Neurosci. 19:141-64

Chandy KG, Fantino E, Wittekindt O, Kalman K, Tong LL, et al. 1998. Isolation of a novel potassium channel gene hSKCa3 containing a polymorphic $\mathrm{CAG}$ repeat: a candidate for schizophrenia and bipolar disorder? Mol. Psychiatr. 3:32-37

Charlier C, Singh NA, Ryan SG, Lewis TB, Reus BE, et al. 1998. A pore mutation in a novel KQT-like potassium channel gene in an idiopathic epilepsy family. Nat. Genet. 18:53-55
Charnet P, Labarca C, Leonard RJ, Vogelaar NJ, Czyzyk L, et al. 1990. An open-channel blocker interacts with adjacent turns of $\alpha$ helices in the nicotinic acetylcholine receptor. Neuron 2:87-95

Chen HI, Sudol M. 1995. The WW domain of Yes-associated protein binds a proline-rich ligand that differs from the consensus established for Src homology 3-binding modules. Proc. Natl. Acad. Sci. USA 92:7819-23

Chen J, Zou A, Splawski I, Keating M, Sanguinetti M. 1999. Long QT syndrome-associated mutations in the Per-Arnt-Sim (PAS) domain of HERG potassium channels accelerate channel deactivation. J. Biol. Chem. 274:10113-18

Chen Q, Kirsch GE, Zhang D, Brugada R, Brugada J, et al. 1998. Genetic basis and molecular mechanism for idiopathic ventricular fibrillation. Nature 392:293-96

Collawn JF, Stangel M, Kuhn LA, Esekogwu V, Jing SQ, et al. 1990. Transferrin receptor internalization sequence YXRF implicates a tight turn as the structural recognition motif for endocytosis. Cell 63:1061-72

Cotecchia S, Exum S, Caron MG, Lefkowitz RJ. 1990. Regions of the $\alpha_{1}$-adrenergic receptor involved in coupling to phosphatidylinositol hydrolysis and enhanced sensitivity of biological function. Proc. Natl. Acad. Sci. USA 87:2896-900

Cox GA, Lutz CM, Yang CL, Biemesderfer D, Bronson RT, et al. 1997. Sodium/hydrogen exchanger gene defect in slow-wave epilepsy mutant mice. Cell 91:139-48

Curran ME, Splawski I, Timothy KW, Vincent GM, Green ED, et al. 1995. A molecular basis for cardiac arrhythmia: HERG mutations cause long QT syndrome. Cell 80:795-803

Dang H, Deshpande P, Guy N, Julius D, Lester H. 1999. Knock-in mice carrying a targeted mutation in the 5- $\mathrm{HT}_{3 \mathrm{~A}}$ subunit. Soc. Neurosci. Abstr. 25:In press

De Biasi M, Hartmann HA, Drewe JA, Taglialatela M, Brown AM, et al. 1993. Inacti- 
vation determined by a single site in $\mathrm{K}^{+}$ pores. Pflugers Arch. 422:354-63

Dingledine R, Borges K, Bowie D, Traynelis SF. 1999. The glutamate receptor ion channels. Pharmacol. Rev. 51:7-61

Dinudom A, Harvey KF, Komwatana P, Young JA, Kumar S, et al. 1998. Nedd4 mediates control of an epithelial $\mathrm{Na}^{+}$channel in salivary duct cells by cytosolic $\mathrm{Na}^{+}$. Proc. Natl. Acad. Sci. USA 95:7169-73

DiPasquale E, Keegan KD, Noebels JL. 1997. Increased excitability and inward rectification in layer $\mathrm{V}$ cortical pyramidal neurons in the epileptic mutant mouse Stargazer. J. Neurophysiol. 77:621-31

Dong K. 1997. A single amino acid change in the para sodium channel protein is associated with knockdown-resistance (kdr) to pyrethroid insecticides in German cockroach. Insect Biochem. Mol. Biol. 27:93100

Dong K, Scott JG. 1994. Linkage of kdr-type resistance and the para-homologous sodium channel gene in German cockroaches (Blattella germanica). Insect Biochem. Mol. Biol. 24:647-54

Doyle D, Cabral JM, Pfuetzner R, Kuo A, Gulbis J, et al. 1998. The structure of the potassium channel: molecular basis of $\mathrm{K}^{+}$ conduction and selectivity. Science 280:6977

Driscoll M. 1992. Molecular genetics of cell death in the nematode Caenorhabditis elegans. J. Neurobiol. 23:1327-51

Dryja TP, Berson EL, Rao VR, Oprian DD. 1993. Heterozygous missense mutation in the rhodopsin gene as a cause of congenital stationary night blindness. Nat. Genet. 4:280-83

Dumaine R, Kirsch GE. 1998. Mechanism of lidocaine block of late current in long Q-T mutant $\mathrm{Na}^{+}$channels. Am. J. Physiol. 274:H477-87

Ehrengruber ME, Doupnik CA, Xu Y, Garvey J, Jasek MC, et al. 1997. Activation of heteromeric $\mathrm{G}$ protein-gated inward rectifier $\mathrm{K}^{+}$channels over-expressed by adenovirus gene transfer inhibits the excitability of hip- pocampal neurons. Proc. Natl. Acad. Sci. USA 94:7070-75

Elkes DA, Cardozo DL, Madison J, Kaplan JM. 1997. EGL-36 Shaw channels regulate C. elegans egg-laying muscle activity. Neuron 19:165-74

Engel A, Lambert E, Mulder D, Torres C, Sahashi K, et al. 1992. A newly recognized congenital myasthenic syndrome attributed to a prolonged open time of the acetylcholine-induced ion channel. Ann. Neurol. 11:553-69

Engel AG, Ohno K, Milone M, Wang HL, Nakano S, et al. 1996. New mutations in acetylcholine-receptor subunit genes reveal heterogeneity in the slow-channel congenital myasthenic syndrome. Hum. Mol. Genet. 5:1217-27

Engel AG, Ohno K, Sine SM. 1999. Congenital myasthenic syndromes: recent advances. Arch. Neurol. 56:163-67

Featherstone DE, Fujimoto E, Ruben PC. 1998. A defect in skeletal muscle sodium channel deactivation exacerbates hyperexcitability in human paramyotonia congenita. J. Physiol. 506:627-38

Feldmeyer D, Kask K, Brusa R, Kornau HC, Kolhekar R, et al. 1999. Neurological dysfunctions in mice expressing different levels of the $\mathrm{Q} / \mathrm{R}$ site-unedited AMPAR subunit GluR-B. Nat. Neurosci. 2:57-64

Feng G, Deak P, Chopra M, Hall LM. 1995. Cloning and functional analysis of TipE, a novel membrane protein that enhances Drosophila para sodium channel function. Cell 82:1001-11

Figl A, Viseshakul N, Shafaee N, Forsayeth J, Cohen BN. 1998. Two mutations linked to nocturnal frontal lobe epilepsy cause usedependent potentiation of the nicotinic ACh response. J. Physiol. 513:655-70

Fletcher CF, Lutz CM, O'Sullivan TN, Shaughnessy JD Jr, Hawkes R, et al. 1996. Absence epilepsy in tottering mutant mice is associated with calcium channel defects. Cell 87:607-17

Forman SA, Yellen G, Thiele EA. 1996. Alternative mechanism for pathogenesis of an 
inherited epilepsy by a nicotinic AchR mutation. Nat. Genet. 13:396-397

Fox AP, Dlouhy S, Ghetti B, Hurley JH, Nucifora $\mathrm{PG}$, et al. 1998. Altered responses to potassium in cerebellar neurons from weaver heterozygote mice. Exp. Brain Res. 123:298-306

Gao W-Q, Hatten ME. 1993. Neuronal differentiation rescued by implantation of weaver granule cell precursors into wild-type cerebellar cortex. Science 260:367-69

Gao W-Q, Liu X-L, Hatten ME. 1992. The weaver gene encodes a nonautonomous signal for CNS neuronal differentiation. Cell 68:841-54

Garcia-Anoveros J, Derfler B, Neville-Golden J, Hyman BT, Corey DP. 1997. BNaC1 and $\mathrm{BNaC} 2$ constitute a new family of human neuronal sodium channels related to degenerins and epithelial sodium channels. Proc. Natl. Acad. Sci. USA 94:1459-64

Garcia-Anoveros J, Garcia JA, Liu JD, Corey DP. 1998. The nematode degenerin UNC105 forms ion channels that are activated by degeneration- or hypercontraction-causing mutations. Neuron 20:1231-41

Garcia-Anoveros J, Ma C, Chalfie M. 1995. Regulation of Caenorhabditis elegans degenerin proteins by a putative extracellular domain. Curr. Biol. 5:441-48

Giese K, Storm J, Reuter D, Fedorov N, Shao L, et al. 1998. Reduced K + channel inactivation, spike broadening, and after-hyperpolarization in $\mathrm{Kv} \beta 1.1$-deficient mice with impaired learning. Learn. Mem. 5:257-73

Gomez CM, Bhattacharyya BB, Charnet P, Day JW, Labarca C, et al. 1996a. A transgenic mouse model of the slow-channel syndrome. Muscle Nerve 19:79-87

Gomez CM, Gammack JT. 1995. A leucine-tophenylalanine substitution in the acetylcholine receptor ion channel in a family with the slow-channel syndrome. Neurology 45:982-85

Gomez CM, Maselli R, Gammack J, Lasalde J, Tamamizu S, et al. 1996b. A $\beta$-subunit mutation in the acetylcholine receptor chan- nel gate causes severe slow-channel syndrome. Ann. Neurol. 39:712-23

Gomez CM, Maselli R, Gundeck JE, Chao M, Day JW, et al. 1997. Slow-channel transgenic mice: a model of postsynaptic organellar degeneration at the neuromuscular junction. J. Neurosci. 17:4170-79

Gomez CM, Maselli R, Williams JM, Bhattacharyya BB, Wollmann RL, et al. 1998. Genetic manipulation of AChR responses suggests multiple causes of weakness in slow-channel syndrome. Ann. NY Acad. Sci. 841:167-80

Goulet CC, Volk KA, Adams CM, Prince LS, Stokes JB, et al. 1998. Inhibition of the epithelial $\mathrm{Na}^{+}$channel by interaction of Nedd4 with a PY motif deleted in Liddle's syndrome. J. Biol. Chem. 273:30012-17

Hansson JH, Nelson-Williams C, Suzuki H, Schild L, Shimkets R, et al. 1995a. Hypertension caused by a truncated epithelial sodium channel $\gamma$ subunit: genetic heterogeneity of Liddle syndrome. Nat. Genet. 11:76-82

Hansson JH, Schild L, Lu Y, Wilson TA, Gautschi I, et al. 1995b. A de novo missense mutation of the $\beta$ subunit of the epithelial sodium channel causes hypertension and Liddle syndrome, identifying a proline-rich segment critical for regulation of channel activity. Proc. Natl. Acad. Sci. USA 92:11495-99

Harkins A, Won L, Heller A, Dlouhy S, Feng $\mathrm{Y}$, et al. 1998. Intracellular calcium is elevated in weaver homozygote and heterozygote cerebellar granule cells. Soc. Neurosci. Abstr. 24:829

Harrison SM, Roffler-Tarlov SK. 1998. Cell death during development of testis and cerebellum in the mutant mouse weaver. Dev. Biol. 195:174-86

Hayward LJ, Brown RH Jr, Cannon SC. 1996. Inactivation defects caused by myotoniaassociated mutations in the sodium channel III-IV linker. J. Gen. Physiol. 107:559-76

Heginbotham L, Lu Z, Abramson T, MacKinnon R. 1994. Mutations in the $\mathrm{K}^{+}$chan- 
nel signature sequence. Biophys. J. 66: 1061-67

Ho IH, Murrell-Lagnado RD. 1999. Molecular determinants for sodium-dependent activation of $\mathrm{G}$ protein-gated $\mathrm{K}^{+}$channels. $J$. Biol. Chem. 274:8639-48

Huang M, Chalfie M. 1994. Gene interactions affecting mechanosensory transduction in Caenorhabditis elegans. Nature 367:46770

Inanobe A, Yoshimoto Y, Horio Y, Morishige KI, Hibino H, et al. 1999. Characterization of G-protein-gated $\mathrm{K}^{+}$channels composed of Kir3.2 subunits in dopaminergic neurons of the substantia nigra. J. Neurosci. 19:1006-17

Isom LL, De Jongh KS, Patton DE, Reber BF, Offord J, et al. 1992. Primary structure and functional expression of the $\beta_{1}$-subunit of the rat brain sodium channel. Science 256:839-42

Jay SD, Ellis SB, McCue AF, Williams ME, Vedvick TS, et al. 1990. Primary structure of the $\gamma$ subunit of the DHP-sensitive calcium channel from skeletal muscle. Science 248:490-92

Jentsch TJ, Lorenz C, Pusch M, Steinmeyer K. 1995. Myotonias due to CLC-1 chloride channel mutations. Soc. Gen. Physiol. Ser. 50:149-59

Jia Z, Agopyan N, Miu P, Xiong Z, Henderson J, et al. 1996. Enhanced LTP in mice deficient in the AMPA receptor GluR2. Neuron 17:945-56

Johns DC, Marx R, Mains RE, O'Rourke B, Marban E. 1999. Inducible genetic suppression of neuronal excitability. J. Neurosci. 19:1691-97

Johnstone DB, Wei A, Butler A, Salkoff L, Thomas JH. 1997. Behavioral defects in $C$. elegans egl-36 mutants result from potassium channels shifted in voltage-dependence of activation. Neuron 19:151-64

Kask K, Zamanillo D, Rozov A, Burnashev N, Sprengel R, et al. 1998. The AMPA receptor subunit GluR-B in its Q/R site-unedited form is not essential for brain development and function. Proc. Natl. Acad. Sci. USA 95:13777-82

Keating MT, Sanguinetti MC. 1996. Pathophysiology of ion channel mutations. Curr. Opin. Genet. Dev. 6:326-33

Kjelsberg MA, Cotecchia S, Ostrowski J, Caron MG, Lefkowitz RJ. 1992. Constitutive activation of the $\alpha_{1 \mathrm{~B}}$-adrenergic receptor by all amino acid substitutions at a single site. Evidence for a region which constrains receptor activation. J. Biol. Chem. 267:1430-33

Knipple DC, Doyle KE, Marsella-Herrick PA, Soderlund DM. 1994. Tight genetic linkage between the $k d r$ insecticide resistance trait and a voltage-sensitive sodium channel gene in the house fly. Proc. Natl. Acad. Sci. USA 91:2483-87

Kofuji P, Hofer M, Millen KJ, James H, Millonig JM, Davidson N, et al. 1996. Functional analysis of the mutant weaver GIRK2 potassium channel and rescue of weaver granule cells. Neuron 16:941-52

Krafte DS, Goldin AL, Auld VJ, Dunn RJ, Davidson N, et al. 1990. Inactivation of cloned $\mathrm{Na}$ channels expressed in Xenopus oocytes. J. Gen. Physiol. 96:689-706

Kubisch C, Schroeder BC, Friedrich T, Lütjohann B, El-Amraoui A, et al. 1999. KCNQ4, a novel potassium channel expressed in sensory outer hair cells, is mutated in dominant deafness. Cell 96: 437-46

Kurihara H, Hashimoto K, Kano M, Takayama C, Sakimura K, et al. 1997. Impaired parallel fiber $\rightarrow$ Purkinje cell synapse stabilization during cerebellar development of mutant mice lacking the glutamate receptor $\delta 2$ subunit. J. Neurosci. 17:9613-23

Kuryatov A, Gerzanich V, Nelson M, Olale F, Lindstrom J. 1997. Mutation causing autosomal dominant nocturnal frontal lobe epilepsy alters $\mathrm{Ca}^{2+}$ permeability, conductance, and gating of human $\alpha 4 \beta 2$ nicotinic acetylcholine receptors. J. Neurosci. 17: 9035-47

Labarca C, Nowak M, Zhang H, Tang L, Deshpande $\mathrm{P}$, et al. 1995. Channel gating gov- 
erned symmetrically by conserved leucine residues in the $\mathrm{M} 2$ domain of nicotinic receptors. Nature 376:514-16

Lalouette A, Guenet JL, Vriz S. 1998. Hotfoot mouse mutations affect the $\delta 2$ glutamate receptor gene and are allelic to lurcher. Genomics 50:9-13

Lauritzen I, De Weille J, Adelbrecht C, Lesage F, Murer G, et al. 1997. Comparative expression of the inward rectifier $\mathrm{K}^{+}$channel GIRK2 in the cerebellum of normal and weaver mutant mice. Brain Res. 753:8-17

Lee SH, Smith TJ, Knipple DC, Soderlund DM. 1999. Mutations in the house fly Vssc1 sodium channel gene associated with super$\mathrm{kdr}$ resistance abolish the pyrethroid sensitivity of Vssc1/tipE sodium channels expressed in Xenopus oocytes. Insect Biochem. Mol. Biol. 29:185-94

Lehmann-Horn F, Jurkatt-Rott K. 1999. Voltage-gated ion channels and hereditary disease. Physiol. Rev. In press

Leonard RJ, Labarca C, Charnet P, Davidson N, Lester HA. 1988. Evidence that the M2 membrane-spanning region lines the ion channel pore of the nicotinic receptor. Science 242:1578-81

Leonard S, Gault J, Moore T, Hopkins J, Robinson M, et al. 1998. Further investigation of a chromosome 15 locus in schizophrenia: analysis of affected sibpairs from the NIMH Genetics Initiative. Am. J. Med. Genet. 81:308-12

Lesage F, Guillemare E, Fink M, Duprat F, Heurteaux C, et al. 1995. Molecular properties of neuronal G-protein-activated inwardly rectifying $\mathrm{K}^{+}$channels. J. Biol. Chem. 270:28660-67

Lester HA. 1988. Heterologous expression of excitability proteins: route to more specific drugs? Science 241:1057-63

Letts VA, Felix R, Biddlecome GH, Arikkath J, Mahaffey CL, et al. 1998. The mouse stargazer gene encodes a neuronal $\mathrm{Ca}^{2+}$. channel $\gamma$ subunit. Nat. Genet. 19:340-47

Liesi P, Wright JM. 1996. Weaver granule neurons are rescued by calcium channel antagonists and antibodies against a neurite outgrowth domain of the B2 chain of laminin. J. Cell. Biol. 134:477-86

Liesi P, Wright JM, Krauthamer V. 1997. BAPTA-AM and ethanol protect cerebellar granule neurons from the destructive effect of the weaver gene. J. Neurosci. Res. 48:571-79

Lifton RP. 1995. Genetic determinants of human hypertension. Proc. Natl. Acad. Sci. USA 92:8545-51

Lingueglia E, Champigny G, Lazdunski M, Barbry P. 1995. Cloning of the amiloridesensitive FMRFamide peptide-gated sodium channel. Nature 378:730-33

Lingueglia E, de Weille JR, Bassilana F, Heurteaux C, Sakai H, et al. 1997. A modulatory subunit of acid sensing ion channels in brain and dorsal root ganglion cells. J. Biol. Chem. 272:29778-83

Liu J, Schrank B, Waterston RH. 1996. Interaction between a putative mechanosensory membrane channel and a collagen. Science 273:361-64

Lorenzon NM, Lutz CM, Frankel WN, Beam KG. 1998. Altered calcium channel currents in Purkinje cells of the neurological mutant mouse leaner. J. Neurosci. 18: 4482-89

Loughney K, Kreber R, Ganetzky B. 1989. Molecular analysis of the para locus, a sodium channel gene in Drosophila. Cell 58:1143-54

Luscher C, Jan LY, Stoffel M, Malenka RC, Nicoll RA. 1997. G protein-coupled inwardly rectifying $\mathrm{K}^{+}$channels (GIRKs) mediate postsynaptic but not presynaptic transmitter actions in hippocampal neurons. Neuron 19:687-95

Malhotra AK, Goldman D. 1999. Benefits and pitfalls encountered in psychiatric genetic association studies. Biol. Psychiatr. 45: 544-50

Martinez-Torres D, Chandre F, Williamson MS, Darriet F, Berge JB, et al. 1998. Molecular characterization of pyrethroid knockdown resistance $(\mathrm{kdr})$ in the major malaria vector Anopheles gambiae s.s. Insect Mol. Biol. 7:179-84 
McEnery MW, Copeland TD, Vance CL. 1998. Altered expression and assembly of $\mathrm{N}$-type calcium channel $\alpha 1 \mathrm{~B}$ and $\beta$ subunits in epileptic lethargic $(l h / l h)$ mouse. J. Biol. Chem. 273:21435-38

McGue M, Bouchard TJ Jr. 1998. Genetic and environmental influences on human behavioral differences. Annu. Rev. Neurosci. 21:1-24

Meiri N, Ghelardini C, Tesco G, Galeotti N, Dahl D, et al. 1997. Reversible antisense inhibition of Shaker-like Kv1.1 potassium channel expression impairs associative memory in mouse and rat. Proc. Natl. Acad. Sci. USA 94:4430-34

Meiri N, Sun MK, Segal Z, Alkon DL. 1998. Memory and long-term potentiation (LTP) dissociated: normal spatial memory despite CA1 LTP elimination with Kv1.4 antisense. Proc. Natl. Acad. Sci. USA 95:15037-42

Milone M, Wang HL, Ohno K, Fukudome T, Pruitt JN, et al. 1997. Slow-channel myasthenic syndrome caused by enhanced activation, desensitization, and agonist binding affinity attributable to mutation in the M2 domain of the acetylcholine receptor a subunit. J. Neurosci. 17:5651-65

Miyazaki M, Ohyama K, Dunlap DY, Matsumura F. 1996. Cloning and sequencing of the para-type sodium channel gene from susceptible and $k d r$-resistant German cockroaches (Blattella germanica) and house fly (Musca domestica). Mol. Gen. Genet. 252:61-68

Mjaatvedt AE, Cabin DE, Cole SE, Long LJ, Breitwieser GE, et al. 1995. Assessment of a mutation in the H5 domain of GIRK2 as a candidate for the weaver mutation. Genome Res. 5:453-63

Nadeau H, Greif G, Crotty D, Khakh B, Anderson D, et al. 1999. ROMK1 (Kir1.1) silences central neurons in vitro and in vivo. Soc. Neurosci. Abstr. 25:In press

Nagatomo T, Fan Z, Ye B, Tonkovich GS, January CT, et al. 1998. Temperature dependence of early and late currents in human cardiac wild-type and long Q-T DKPQ $\mathrm{Na}^{+}$ channels. Am. J. Physiol. 275:H2016-24
Navarro B, Kennedy ME, Velimirovic B, Bhat D, Peterson AS, et al. 1996. Nonselective and $\mathrm{Gb} \gamma$-insensitive weaver $\mathrm{K}^{+}$channels. Science 272:1950-53

Neyroud N, Tesson F, Denjoy I, Leibovici M, Donger C, et al. 1997. A novel mutation in the potassium channel gene KVLQT1 causes the Jervell and Lange-Nielsen cardioauditory syndrome. Nat. Genet. 15:18689

Niswender CM, Copeland SC, Herrick-Davis K, Emeson RB, Sanders-Bush E. 1999. RNA editing of the human serotonin 5hydroxytryptamine $2 \mathrm{C}$ receptor silences constitutive activity. J. Biol. Chem. 274:9472-78

Ohno K, Hutchinson DO, Milone M, Brengman JM, Bouzat C, et al. 1995. Congenital myasthenic syndrome caused by prolonged acetylcholine receptor channel openings due to a mutation in the M2 domain of the epsilon subunit. Proc. Natl. Acad. Sci. USA 92:758-62

Park Y, Taylor MF. 1997. A novel mutation L1029H in sodium channel gene hscp associated with pyrethroid resistance for Heliothis virescens (Lepidoptera: Noctuidae). Insect Biochem. Mol. Biol. 27:9-13

Park Y, Taylor MF, Feyereisen R. 1997. A valine421 to methionine mutation in IS6 of the hscp voltage-gated sodium channel associated with pyrethroid resistance in Heliothis virescens F. Biochem. Biophys. Res. Commun. 239:688-91

Parma J, Duprez L, Van Sande J, Cochaux P, Gervy C, et al. 1993. Somatic mutations in the thyrotropin receptor gene cause hyperfunctioning thyroid adenomas. Nature 365:649-51

Patil N, Cox DR, Bhat D, Faham M, Myers RM, et al. 1995. A potassium channel mutation in weaver mice implicates membrane excitability in granule cell differentiation. Nat. Genet. 11:126-29

Pittendrigh B, Reenan R, French-Constant RH, Ganetzky B. 1997. Point mutations in the Drosophila sodium channel gene para associated with resistance to DDT and pyre- 
throid insecticides. Mol. Gen. Genet. 256:602-10

Pragnell M, De Waard M, Mori Y, Tanabe T, Snutch TP, et al. 1994. Calcium channel $\beta$ subunit binds to a conserved motif in the III cytoplasmic linker of the $\alpha_{1}$ subunit. Nature 368:67-70

Price MP, Snyder PM, Welsh MJ. 1996. Cloning and expression of a novel human brain $\mathrm{Na}^{+}$channel. J. Biol. Chem. 271:7879-82

Qiao X, Chen L, Gao H, Bao S, Hefti F, et al. 1998. Cerebellar brain-derived neurotrophic factor-TrkB defect associated with impairment of eyeblink conditioning in Stargazer mutant mice. J. Neurosci. 18:6990-99

Qiao X, Hefti F, Knusel B, Noebels JL. 1996. Selective failure of brain-derived neurotrophic factor mRNA expression in the cerebellum of stargazer, a mutant mouse with ataxia. J. Neurosci. 16:640-48

Ramaswami M, Tanouye MA. 1989. Two sodium-channel genes in Drosophila: implications for channel diversity. Proc. Natl. Acad. Sci. USA 86:2079-82

Rao VR, Cohen GB, Oprian DD. 1994. Rhodopsin mutation G90D and a molecular mechanism for congenital night blindness. Nature 367:639-42

Rao VR, Oprian DD. 1996. Activating mutations of rhodopsin and other $\mathrm{G}$ protein-coupled receptors. Annu. Rev. Biophys. Biomol. Struct. 25:287-314

Revah F, Bertrand D, Galzi JL, DevillersTheiry A, Mulle C. 1991. Mutations in the channel domain alter desensitization of a neuronal nicotinic receptor. Nature 353:846-49

Richmond JE, Van De Carr D, Featherstone DE, George AL Jr, Ruben PC. 1997. Defective fast inactivation recovery and deactivation account for sodium channel myotonia in the I1160V mutant. Biophys. J. 73:1896-903

Robinson PR, Cohen GB, Zhukovsky EA, Oprian DD. 1992. Constitutively active mutants of rhodopsin. Neuron 9:719-25
Roffler-Tarlov S, Martin B, Graybiel AM, Kauer JS. 1996. Cell death in the midbrain of the murine mutation weaver. J. Neurosci. 16:1819-26

Ruff RL. 1998. Cells use the singular properties of different channels to produce unique electrical songs. Biophys. J. 74:2745-46

Russell MW, Dick M II, Collins FS, Brody LC. 1996. KVLQT1 mutations in three families with familial or sporadic long QT syndrome. Hum. Mol. Genet. 5:1319-24

Sanguinetti MC, Curran ME, Spector PS, Keating MT. 1996. Spectrum of HERG K ${ }^{+}$channel dysfunction in an inherited cardiac arrhythmia. Proc. Natl. Acad. Sci. USA 93:2208-12

Sanguinetti MC, Jiang C, Curran ME, Keating MT. 1995. A mechanistic link between an inherited and an acquired cardiac arrhythmia: HERG encodes the $I_{K r}$ potassium channel. Cell 81:299-307

Sanguinetti MC, Jurkiewicz NK. 1990. Two components of cardiac delayed rectifier $\mathrm{K}^{+}$ current. Differential sensitivity to block by class III antiarrhythmic agents. J. Gen. Physiol. 96:195-215

Scheer A, Cotecchia S. 1997. Constitutively active $\mathrm{G}$ protein-coupled receptors: potential mechanisms of receptor activation. $J$. Recept. Signal Transduct. Res. 17:57-73

Schein JC, Hunter DD, Roffler-Tarlov S. 1998. Girk2 expression in the ventral midbrain, cerebellum, and olfactory bulb and its relationship to the murine mutation weaver. Dev. Biol. 204:432-50

Schild L, Lu Y, Gautschi I, Schneeberger E, Lifton RP, et al. 1996. Identification of a PY motif in the epithelial Na channel subunits as a target sequence for mutations causing channel activation found in Liddle syndrome. EMBO J. 15:2381-87

Schonherr R, Heinemann SH. 1996. Molecular determinants for activation and inactivation of HERG, a human inward rectifier potassium channel. J. Physiol. 493:635-42

Schott JJ, Charpentier F, Peltier S, Foley P, Drouin E, et al. 1995. Mapping of a gene 
for long QT syndrome to chromosome 4q25-27. Am. J. Hum. Genet. 57:1114-22

Schroeder BC, Kubisch C, Stein V, Jentsch TJ. 1998. Moderate loss of function of cyclicAMP-modulated KCNQ2/KCNQ3 $\mathrm{K}^{+}$ channels causes epilepsy. Nature 396:68790

Schulze-Bahr E, Wang Q, Wedekind H, Haverkamp W, Chen Q, et al. 1997. KCNE1 mutations cause Jervell and Lange-Nielsen syndrome. Nat. Genet. 17:267-68

Seeburg PH, Higuchi M, Sprengel R. 1998. RNA editing of brain glutamate receptor channels: mechanism and physiology. Brain Res. Brain Res. Rev. 26:217-29

Sekiguchi M, Nowakowski RS, Nagato Y, Tanaka O, Guo H, et al. 1995. Morphological abnormalities in the hippocampus of the weaver mutant mouse. Brain Res. 696:262-67

Shenker A. 1995. G protein-coupled receptor structure and function: the impact of disease-causing mutations. Baillières Clin. Endocrinol. Metab. 9:427-51

Shenker A, Laue L, Kosugi S, Merendino JJ Jr, Minegishi T, et al. 1993. A constitutively activating mutation of the luteinizing hormone receptor in familial male precocious puberty. Nature 365:652-54

Shimkets RA, Lifton RP, Canessa CM. 1997. The activity of the epithelial sodium channel is regulated by clathrin-mediated endocytosis. J. Biol. Chem. 272:25537-41

Shreffler W, Magardino T, Shekdar K, Wolinsky E. 1995. The unc- 8 and sup-40 genes regulate ion channel function in Caenorhabditis elegans motorneurons. Genetics 139:1261-72

Signorini S, Liao YJ, Duncan SA, Jan LY, Stoffel M. 1997. Normal cerebellar development but susceptibility to seizures in mice lacking $\mathrm{G}$ protein-coupled, inwardly rectifying $\mathrm{K}^{+}$channel GIRK2. Proc. Natl. Acad. Sci. USA 94:923-27

Silverman S, Lester H, Dougherty D. 1998. Asymmetrical contributions of subunit pore regions to ion selectivity in an inward rectifier $\mathrm{K}^{+}$channel. Biophys. J. 75:1330-39
Silverman SK, Kofuji P, Dougherty DA, Davidson N, Lester HA. 1996. A regenerative link in the ionic fluxes through the weaver potassium channel underlies the pathophysiology of the mutation. Proc. Natl. Acad. Sci. USA 93:15429-34

Sine SM, Ohno K, Bouzat C, Auerbach A, Milone M, et al. 1995. Mutation of the acetylcholine receptor a subunit causes a slow-channel myasthenic syndrome by enhancing agonist binding affinity. Neuron 15:229-39

Singh NA, Charlier C, Stauffer D, DuPont BR, Leach RJ, et al. 1998. A novel potassium channel gene, $K C N Q 2$, is mutated in an inherited epilepsy of newborns. Nat. Genet. 18:25-29

Slesinger PA, Patil N, Liao YJ, Jan YN, Jan LY, et al. 1996. Functional effects of the mouse weaver mutation on $\mathrm{G}$ protein-gated inwardly rectifying $\mathrm{K}^{+}$channels. Neuron 16:321-31

Slesinger PA, Stoffel M, Jan YN, Jan LY. 1997. Defective $\gamma$-aminobutyric acid type B receptor-activated inwardly rectifying $\mathrm{K}^{+}$ currents in cerebellar granule cells isolated from weaver and Girk2 null mutant mice. Proc. Natl. Acad. Sci. USA 94:12210-17

Smart SL, Lopantsev V, Zhang CL, Robbins CA, Wang H, et al. 1998. Deletion of the $\mathrm{K}_{\mathrm{V}} 1.1$ potassium channel causes epilepsy in mice. Neuron 20:809-19

Smith PL, Baukrowitz T, Yellen G. 1996. The inward rectification mechanism of the HERG cardiac potassium channel. Nature 379:833-36

Smith TJ, Lee SH, Ingles PJ, Knipple DC, Soderlund DM. 1997. The L1014F point mutation in the house fly Vsscl sodium channel confers knockdown resistance to pyrethroids. Insect Biochem. Mol. Biol. 27:807-12

Snyder PM, Cheng C, Prince LS, Rogers JC, Welsh MJ. 1998. Electrophysiological and biochemical evidence that DEG/ENaC cation channels are composed of nine subunits. J. Biol. Chem. 273:681-84

Snyder PM, Price MP, McDonald FJ, Adams CM, Volk KA, et al. 1995. Mechanism by 
which Liddle's syndrome mutations increase activity of a human epithelial $\mathrm{Na}^{+}$ channel. Cell 83:969-78

Sommer B, Kohler M, Sprengler R, Seeburg PH. 1991. RNA editing in brain controls a determinant of ion flow in glutamate-gated channels. Cell 67:11-19

Spauschus A, Eunson L, Hanna M, Kullmann D. 1998. Functional characterization of a novel mutation in KCNA1 in episodic ataxia type 1assiciated with epilepsy. Ann. NY Acad. Sci. 868:442-46

Spiegel AM. 1996. Mutations in G proteins and $\mathrm{G}$ protein-coupled receptors in endocrine disease. J. Clin. Endocrinol. Metab. 81:2434-42

Spiegel AM. 1997. Inborn errors of signal transduction: mutations in $\mathrm{G}$ proteins and $\mathrm{G}$ protein-coupled receptors as a cause of disease. J. Inherit. Metab. Dis. 20:113-21

Splawski I, Timothy KW, Vincent GM, Atkinson DL, Keating MT. 1997. Molecular basis of the long-QT syndrome associated with deafness. N. Engl. J. Med. 336:156267

Staley K, Smith R, Schaack J, Wilcox C, Jentsch TJ. 1996. Alteration of $\mathrm{GABA}_{\mathrm{A}}$ receptor function following gene transfer of the CLC-2 chloride channel. Neuron 17:543-51

Staub O, Dho S, Henry P, Correa J, Ishikawa T, et al. 1996. WW domains of Nedd4 bind to the proline-rich PY motifs in the epithelial $\mathrm{Na}^{+}$channel deleted in Liddle's syndrome. EMBO J. 15:2371-80

Steinlein OK, Magnusson A, Stoodt J, Bertrand S, Weiland S, et al. 1997. An insertion mutation of the CHRNA4 gene in a family with autosomal dominant nocturnal frontal lobe epilepsy. Hum. Mol. Genet. 6:943-47

Stober G, Jatzke S, Meyer J, Okladnova O, Knapp M, et al. 1998. Short CAG repeats within the hSKCa3 gene associated with schizophrenia: results of a family-based study. NeuroReport 9:3595-99

Stoffel M, Jan LY. 1998. Epilepsy genes: excitement traced to potassium channels. Nat. Genet. 18:6-8
Sui JL, Chan KW, Logothetis DE. 1996. $\mathrm{Na}^{+}$ activation of the muscarinic $\mathrm{K}^{+}$channel by a G-protein-independent mechanism. $J$. Gen. Physiol. 108:381-91

Surmeier D, Nucifora PG, Goldowitz D. 1996. The weaver mutation of GIRK2 results in a loss of inwardly rectifying $\mathrm{K}^{+}$current in cerebellar granule cells. Proc. Natl. Acad. Sci. USA 93:11191-95

Sutherland ML, Williams SH, Abedi R, Overbeek PA, Pfaffinger PJ, et al. 1999. Overexpression of a Shaker-type potassium channel in mammalian central nervous system dysregulates native potassium channel gene expression. Proc. Natl. Acad. Sci. USA 96:2451-55

Takayama C, Nakagawa S, Watanabe M, Mishina M, Inoue Y. 1996. Developmental changes in expression and distribution of the glutamate receptor channel $\delta 2$ subunit according to the Purkinje cell maturation. Brain Res. Dev. Brain Res. 92:147-55

Tavernarakis N, Driscoll M. 1997. Molecular modeling of mechanotransduction in the nematode Caenorhabditis elegans. Annu. Rev. Physiol. 59:659-89

Tinel N, Lauritzen I, Chouabe C, Lazdunski M, Borsotto M. 1998. The KCNQ2 potassium channel: splice variants, functional and developmental expression. Brain localization and comparison with KCNQ3. FEBS Lett. 438:171-76

Tong Y, Wei J, Zhang S, Strong JA, Dlouhy SR, et al. 1996. The weaver mutation changes the ion selectivity of the affected inwardly rectifying potassium channel GIRK2. FEBS Lett. 390:63-68

Treinin M, Chalfie M. 1995. A mutated acetylcholine receptor subunit causes neuronal degeneration in C. elegans. Neuron 14: 871-77

Treinin M, Gillo B, Liebman L, Chalfie M. 1998. Two functionally dependent acetylcholine subunits are encoded in a single Caenorhabditis elegans operon. Proc. Natl. Acad. Sci. USA 95:15492-95

Trudeau MC, Warmke JW, Ganetzky B, Robertson GA. 1995. HERG, a human inward 
rectifier in the voltage-gated potassium channel family. Science 269:92-95

Tucker SJ, Pessia M, Moorhouse AJ, Gribble F, Ashcroft FM, et al. 1996. Heteromeric channel formation and $\mathrm{Ca}^{2+}$-free media reduce the toxic effect of the weaver $\mathrm{K}_{\mathrm{ir}} 3.2$ allele. FEBS Lett. 390:253-57

Tyson J, Tranebjaerg L, Bellman S, Wren C, Taylor JF, et al. 1997. $\mathrm{I}_{\mathrm{sK}}$ and KvLQT1: mutation in either of the two subunits of the slow component of the delayed rectifier potassium channel can cause Jervell and Lange-Nielsen syndrome. Hum. Mol. Genet. 6:2179-85

Velimirovic BM, Koyano K, Nakajima S, Nakajima Y. 1995. Opposing mechanisms of regulation of a $\mathrm{G}$ protein-coupled inward rectifier $\mathrm{K}$ channel in rat brain neurons. Proc. Natl. Acad. Sci. USA 92:1590-94

Vetter DE, Mann JR, Wangemann P, Liu J, McLaughlin KJ, et al. 1996. Inner ear defects induced by null mutation of the isk gene. Neuron 17:1251-64

Wakamori M, Yamazaki K, Matsunodaira H, Teramoto T, Tanaka I, et al. 1998. Single tottering mutations responsible for the neuropathic phenotype of the P-type calcium channel. J. Biol. Chem. 273:34857-67

Waldmann R, Champigny G, Voilley N, Lauritzen I, Lazdunski M. 1996. The mammalian degenerin MDEG, an amiloridesensitive cation channel activated by mutations causing neurodegeneration in Caenorhabditis elegans. J. Biol. Chem. 271:10433-36

Wallace RH, Wang DW, Singh R, Scheffer IE, George AL Jr, et al. 1998. Febrile seizures and generalized epilepsy associated with a mutation in the $\mathrm{Na}^{+}$-channel $\beta 1$ subunit gene SCN1B. Nat. Genet. 19:366-70

Wang HL, Auerbach A, Bren N, Ohno K, Engel AG, et al. 1997. Mutation in the M1 domain of the acetylcholine receptor $\alpha$ subunit decreases the rate of agonist dissociation. J. Gen. Physiol. 109:757-66

Wang HS, Pan Z, Shi W, Brown BS, Wymore RS, et al. 1998. KCNQ2 and KCNQ3 potas- sium channel subunits: molecular correlates of the M-channel. Science 282:1890-93

Wang J, Dubowitz V, Lehmann-Horn F, Ricker K, Ptacek L, et al. 1995a. In vivo sodium channel structure/function studies: consecutive Arg1448 changes to Cys, His, and Pro at the extracellular surface of IVS4. Soc. Gen. Physiol. Ser. 50:77-88

Wang Q, Curran ME, Splawski I, Burn TC, Millholland JM, et al. 1996. Positional cloning of a novel potassium channel gene: KVLQT1 mutations cause cardiac arrhythmias. Nat. Genet. 12:17-23

Wang Q, Shen J, Splawski I, Atkinson D, Li Z, et al. 1995b. SCN5A mutations associated with an inherited cardiac arrhythmia, long QT syndrome. Cell 80:805-11

Warmke JW, Ganetzky B. 1994. A family of potassium channel genes related to eag in Drosophila and mammals. Proc. Natl. Acad. Sci. USA 91:3438-42

Warmke JW, Reenan RA, Wang P, Qian S, Arena JP, et al. 1997. Functional expression of Drosophila para sodium channels. Modulation by the membrane protein TipE and toxin pharmacology. J. Gen. Physiol. 110:119-33

Williamson MS, Denholm I, Bell CA, Devonshire AL. 1993. Knockdown resistance (kdr) to DDT and pyrethroid insecticides maps to a sodium channel gene locus in the housefly (Musca domestica). Mol. Gen. Genet. 240:17-22

Williamson MS, Martinez-Torres D, Hick CA, Devonshire AL. 1996. Identification of mutations in the housefly para-type sodium channel gene associated with knockdown resistance (kdr) to pyrethroid insecticides. Mol. Gen. Genet. 252:51-60

Wollnik B, Schroeder BC, Kubisch C, Esperer HD, Wieacker P, et al. 1997. Pathophysiological mechanisms of dominant and recessive KVLQT1 $\mathrm{K}^{+}$channel mutations found in inherited cardiac arrhythmias. Hum. Mol. Genet. 6:1943-49

Yang WP, Levesque PC, Little WA, Conder ML, Ramakrishnan P, et al. 1998. Functional expression of two KvLQT1-related 
potassium channels responsible for an inherited idiopathic epilepsy. J. Biol. Chem. 273:19419-23

Zhao HM, Wenthold RJ, Petralia RS. 1998. Glutamate receptor targeting to synaptic populations on Purkinje cells is developmentally regulated. J. Neurosci. 18:551728

Zhou M, Engel A, Auerbach A. 1999. Serum choline activates mutant acetylcholine receptors that cause slow channel congenital myasthenic syndromes. Proc. Natl. Acad. Sci. USA. In press

Zhou Z, Gong Q, Epstein ML, January CT. 1998. HERG channel dysfunction in human long QT syndrome. Intracellular transport and functional defects. J. Biol. Chem. 273:21061-66

Zlotkin E. 1999. The insect voltage-gated sodium channel as target of insecticides. Annu. Rev. Entomol. 44:429-55

Zuberi SM, Eunson L, Spauschus A, DeSilva $\mathrm{R}$, Tolmie J, et al. 1999. A novel mutation in the human voltage gated potassium channel gene $\left(K_{V} 1.1\right)$ associates with episodic ataxia type 1 and sometimes with partial epilepsy. Brain. 122:817-825

Zuo J, De Jager PL, Takahashi KA, Jiang W, Linden DJ, et al. 1997. Neurodegeneration in Lurcher mice caused by mutation in $\delta 2$ glutamate receptor gene. Nature 388:769-73 


\section{CONTENTS}

Cortical and Subcortical Contributions to Activity-Dependent Plasticity in Primate Somatosensory Cortex, Edward G. Jones

Microtubule-Based Transport Systems in Neurons: The Roles of Kinesins and Dyneins, Lawrence S. B. Goldstein, Zhaohuai Yang

Apoptosis in Neural Development and Disease, Deepak Nijhawan,

Narimon Honarpour, Xiaodong Wang

Gain of Function Mutants: Ion Channels and G Protein-Coupled

Receptors, Henry A. Lester, Andreas Karschin

The Koniocellular Pathway in Primate Vision, Stewart H. C. Hendry, R.

Clay Reid

Emotion Circuits in the Brain, Joseph E. LeDoux

Dopaminergic Modulation of Neuronal Excitability in the Striatum and

Nucleus Accumbens, Saleem M. Nicola, D. James Surmeier, Robert C.

Malenka

Glutamine Repeats and Neurodegeneration, Huda Y. Zoghbi, Harry T.

Orr

Confronting Complexity: Strategies for Understanding the Microcircuitry

of the Retina, Richard H. Masland, Elio Raviola

Adaptation in Hair Cells, Ruth Anne Eatock

Mechanisms of Visual Attention in the Human Cortex, Sabine Kastner

and Leslie G. Ungerleider

The Emergence of Modern Neuroscience: Some Implications for

Neurology and Psychiatry, W. Maxwell Cowan, Donald H. Harter, Eric

R. Kandel

Plasticity and Primary Motor Cortex, Jerome N. Sanes, John P.

Donoghue

Guanylyl Cyclases as a Family of Putative Odorant Receptors, Angelia D.

Gibson, David L. Garbers

Neural Mechanisms of Orientation Selectivity in the Visual Cortex, David

Ferster, Kenneth D. Miller

Neuronal Coding of Prediction Errors, Wolfram Schultz, Anthony

Dickinson

473

Modular Organization of Frequency Integration in Primary Auditory

Cortex, Christoph E. Schreiner, Heather L. Read, Mitchell L. Sutter

Control of Cell Divisions in the Nervous System: Symmetry and

Asymmetry, Bingwei Lu, Lily Jan, Yuh-Nung Jan

Consciousness, John R. Searle

The Relationship between Neuronal Survival and Regeneration, Jeffrey L.

Goldberg, Ben A. Barres

Neural Representation and the Cortical Code, R. Christopher deCharms, Anthony Zador

Synaptic Plasticity and Memory: An Evaluation of the Hypothesis, S. J.

Martin, P. D. Grimwood, R. G. M. Morris

Molecular Genetics of Circadian Rhythms in Mammals, David P. King, Joseph S. Takahashi

Parallel Pathways for Spectral Coding in Primate Retina, Dennis M.

Dacey

Pain Genes?: Natural Variation and Transgenic Mutants, Jeffrey S. Mogil, 